\title{
What about us? Bringing infertility into reproductive health care
}

Okonofua Friday

Bishakha Datta

Follow this and additional works at: https://knowledgecommons.popcouncil.org/departments_sbsr-pgy

Part of the Family, Life Course, and Society Commons, Gender and Sexuality Commons, International Public Health Commons, Public Health Education and Promotion Commons, and the Women's Health Commons How does access to this work benefit you? Let us know!

\section{Recommended Citation}

Friday, Okonofua and Bishakha Datta. 2002. "What about us? Bringing infertility into reproductive health care," Quality/Calidad/Qualité no. 13. New York: Population Council. 
"What About Us?"

Bringing Infertility Into Reproductive Health Care
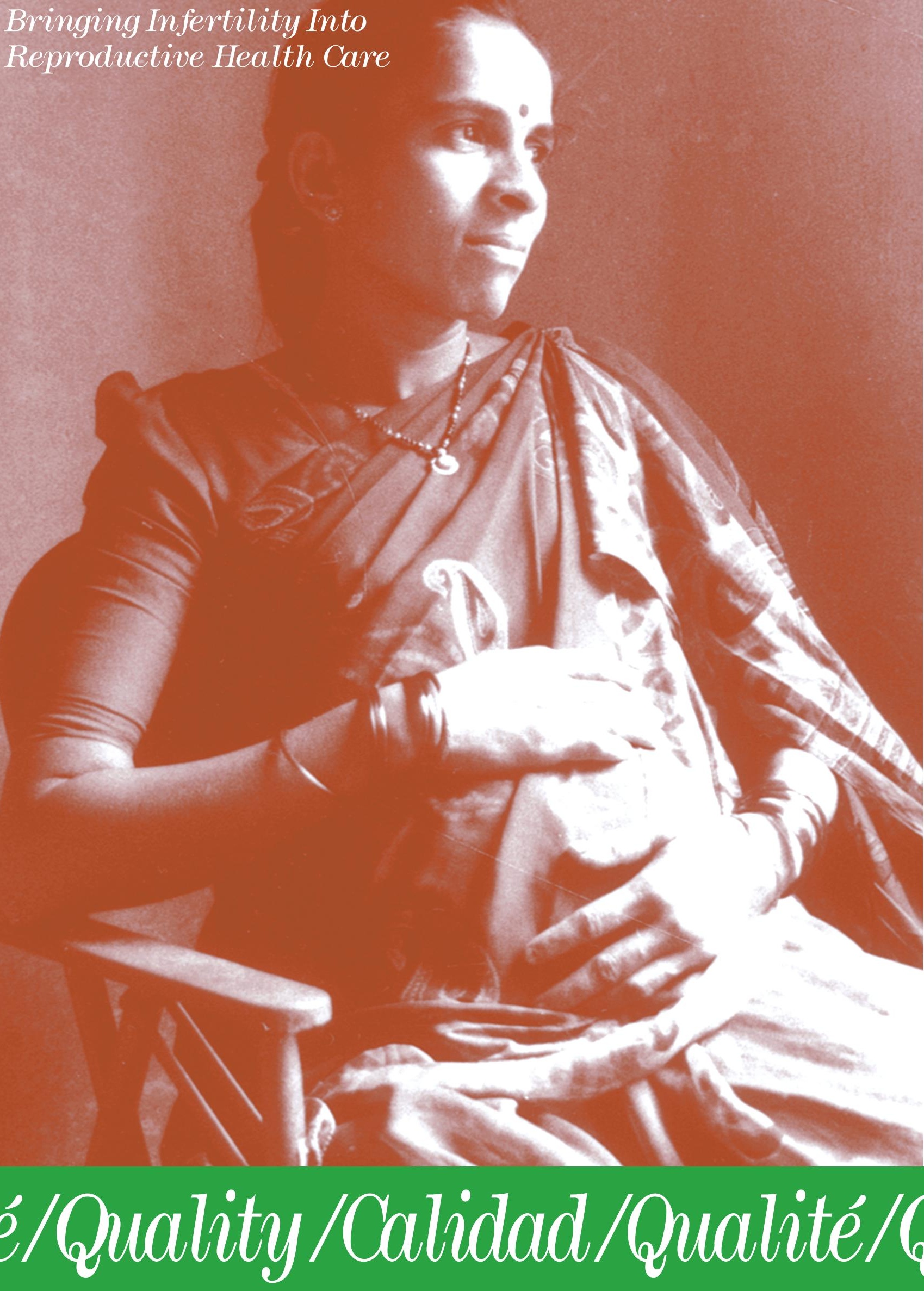



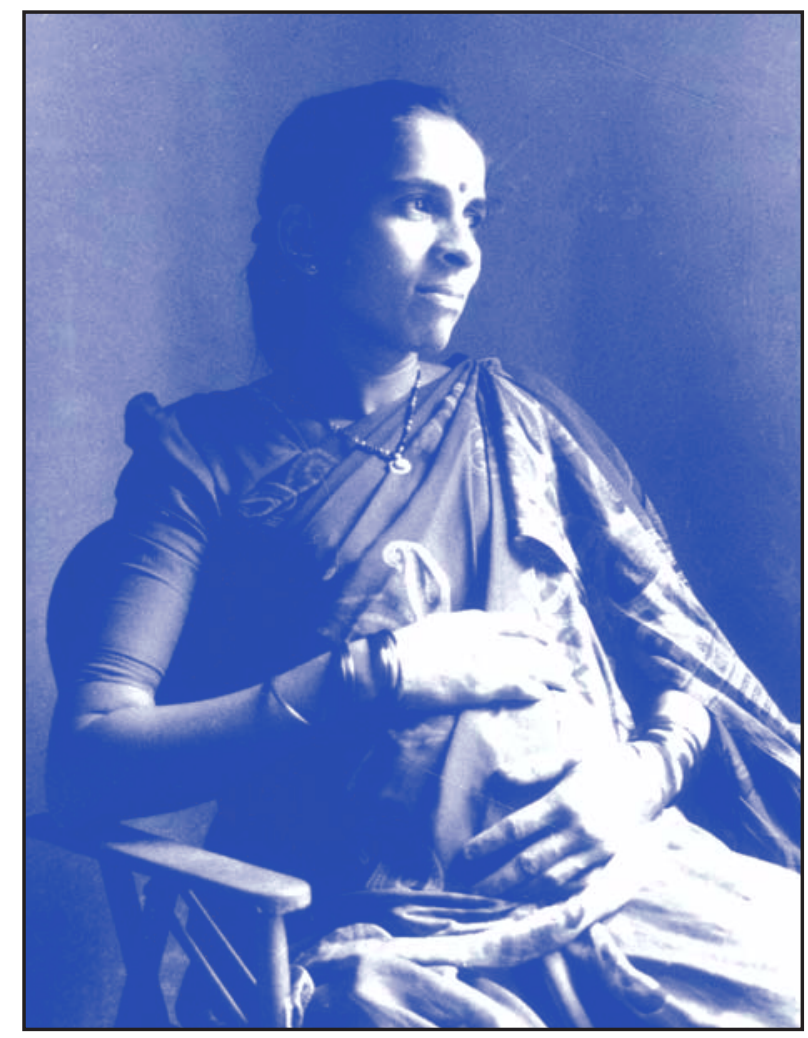

"What About Us?" Bringing Infertility Into Reproductive Health Care 
Quality/Calidad/Qualité, a publication of the Population Council, highlights examples of clinical and educational programs that bring a strong commitment, as well as innovative and thoughtful approaches, to the issue of high-quality care in sexual and reproductive health. The series is based on the philosophy that people have a fundamental right to respectful treatment, information, choice, and follow-up from reproductive health-care providers.

$Q / C / Q$ documents projects that are making important strides in one or more of the following ways: broadening the choice of methods and technologies available; providing the information clients need to make informed choices; enabling clients to become more effective guardians of their sexual and reproductive health; making innovative efforts to increase the management capacity and broaden the skills of service providers at all levels; combining health care, family planning, and related services in an innovative ways; and reaching underserved and disadvantaged groups.
Projects are selected for documentation by an advisory group made up of individuals who have a broad range of experience with promoting quality of care in sexual and reproductive health. None of the projects documented is being offered as a model for replication. Rather, each is presented as an unusually creative example of values, objectives, and implementation. These are learning experiences that demonstrate the self-critical attitude required to anticipate clients' needs and find affordable means to meet them. This reflective posture is exemplified by a willingness to respond to changes in clients' needs as well as to the broader social and economic transformations affecting societies. Documenting the critical choices these programs have made should help to reinforce, in practical terms, the belief that an individual's satisfaction with sexual and reproductive health services is strongly related to the achievement of broader health and population goals.

\section{Population Council}

The Population Council is an international, nonprofit, nongovernmental institution that seeks to improve the well-being and reproductive health of current and future generations around the world and to help achieve a humane, equitable, and sustainable balance between people and resources. The Council conducts biomedical, social science, and public health research and helps build research capacities in developing countries. Established in 1952, the Council is governed by an international board of trustees. Its New York headquarters supports a global network of regional and country offices.

Population Council, One Dag Hammarskjold Plaza, New York, New York 10017 USA tel: (212) 339-0500, fax: (212) 755-6052, e-mail:qcq@ popcouncil.org, http://www.popcouncil.org.

Publication of this edition of Quality/Calidad/Qualité is made possible by support provided by the Ford Foundation, and by the Gender, Family, and Development Program of the Population Council. Statements made and views expressed in this publication are solely the responsibility of the authors and not of any organization providing support for $Q / C / Q$. Any part of this document may be reproduced without permission of the authors so long as it is not sold for profit.

Cover photograph by Tejal Shah.

Number Thirteen 2002 ISSN: 1097-8194

Copyright $(2002$ The Population Council, Inc. 


\section{by Friday Okonofua}

Infertility is a major reproductive health problem throughout much of the world. ${ }^{1}$ Its prevalence in industrialized countries ranges between 6 and 10 percent of women of reproductive age; in developing countries, it may be considerably higher. Sub-Saharan Africa has the highest infertility rate in the world, with prevalence exceeding 15 percent in many countries. An area known as the "infertility belt" stretches through much of Central Africa; Gabon and Democratic Republic of the Congo, for example, have infertility rates in excess of 25 percent (Farley and Belsey 1988). Furthermore, there is increasing evidence that the prevalence of infertility has been rising in many parts of the world. This rise is largely attributable to an increased incidence of infections, especially sexually transmitted infections (STIs) that impair female fertility. Data also exist suggesting a decline in sperm counts in many parts of the world, although the evidence is not conclusive.

The cause of infertility varies to some degree by region. Studies indicate that infertility in developed countries is due mostly to such biological causes as failure of ovulation (which may sometimes be related to a woman's age rather than to endocrine disease) and "unexplained causes" (Cates et al. 1985; WHO 1987). By contrast, in developing countries, and particularly in sub-Saharan Africa, infertility is largely secondary to undiagnosed or poorly treated STIs (neisseria gonorrhea and chlamydia), unsafe abortion, and substandard obstetric conditionsall of which are preventable.

Although involuntary childlessness is a difficult situation for any couple, its social consequences are most accentuated in developing countries and are generally more severe for women than for men. Male infertility is often not acknowledged, and the female partner is typically held responsible for a couple's childlessness. Indeed, in much of Africa, infertility leaves women vulnerable to physical abuse, ostracism, and severe psychological problems, as well as divorce.

Where resources are available, a combination of conventional treatments and new reproductive technologies has enabled providers to resolve infertility in more than 50 percent of cases. Unfortunately, in the developing world, most health programs have fewer options. The new technologies are either unavailable or too expensive for the majority of patients. Few clinics serving the poor have any trained staff or systematic protocols with which to provide infertility services. Furthermore, unlike attitudes in some Western settings, adopting a baby is still considered taboo in many developing country cultures.

Despite the prevalence and seriousness of infertility, the population and reproductive health field has largely neglected this problem. National policies and international donor organizations have been one-sided in their focus on programs designed to prevent unwanted pregnancies. Little emphasis has been placed on "other kinds" of family planning, that is, on assisting couples who are unable to produce children. Although many countries with a high rate of infertility also have elevated rates of unwanted fertility, these two are distinct issues and each needs specific atten-

\footnotetext{
1 Infertility may refer to primary infertility (the woman has never conceived despite extended exposure to the risk of becoming pregnant), secondary infertility (inability to conceive despite previous conception), or pregnancy wastage (ability to conceive but not to produce live offspring) (WHO 1991). Conditions in the male and/or female partner may contribute to infertility.
} 
tion. Undoubtedly, the principles articulated by the 1994 International Conference on Population and Development in Cairo underscore the need to help individuals achieve their reproductive goals, and advocate for holistic approaches to achieving developmental goals.

The time has come to reverse the neglect of infertility and to press for improvement in its prevention and treatment as part of reproductive health care. This issue of $Q / C / Q$, with clinic-based narratives and case reports from India and Nigeria, illustrates what is involved in trying to address the problem of infertility in developing countries. In India, although 10 percent of couples experience infertility at some time in their lives, resources for treatment are scarce. In Bhiwandi (outside Bombay), where infertility care is largely unaffordable in the private sector and unavailable in the public sector, the Family Planning Association of India is providing high-quality, affordable services to infertile couples under its Bhiwandi-based Comprehensive Reproductive Health for All project. In Benin City, Nigeria-where the service options are similarly limited and the prevalence of infertility is now rising above 20 percent-the Women's Health and Action Research Centre offers comprehensive reproductive health care, including management of infertility.

Both programs combine education, counseling, careful history taking, laboratory testing, minor pharmacological and surgical therapies, and referral. Although a number of clinical and economic factors translate into limited success rates, the programs featured in the following pages are enabling some couples to realize their dreams of parenthood. The education and support they provide to distraught couples is also invaluable.

Although the expense and technical expertise of full-scale infertility treatment is beyond the capacity of most organizations, family planning programs can do a great deal that generally they are not currently doing for infertile couples. Family planning programs need to reexamine their view of infertility and consider ways to inform their staff and assist their clients with information and provide at least rudimentary services. Such a reorientation would involve men in reproductive health care, strengthen efforts to reduce STI and reproductive tract infection (RTI) rates, and foster openness toward sexuality issues. Furthermore, by addressing an issue that is both sensitive and neglected, family planning programs can win trust from communities and enhance program use in developing countries around the world. By assisting couples who want to have children as well as those who want to avoid pregnancy, family planning programs will finally become worthy of their name in the truest sense.

A possible framework for incorporating limited infertility care into a family planning or reproductive health program is provided in the Afterword, at the end of this issue. Program leaders would do well to assess how they might adapt such a framework to help meet urgently felt needs in their population. There is little excuse for doing nothing for the many infertile couples to whom we can offer some measure of help and hope.

\section{References}

Cates W., T.M.M. Farley, and P.J. Rowe. 1985. "Worldwide patterns of infertility: Is Africa different?" Lancet 2(8,455): 596-598.

Farley, T.M.M. and E.M. Belsey. 1988. "The prevalence of infertility." In African Population Conference. Dakar: International Union for the Scientific Study of Populations $1: 2,1.15-2.1 .30$.

World Health Organization. 1987. "Infections, pregnancies, and infertility: Perspectives on prevention." Fertility and Sterility 47: 964 968. Geneva: WHO.

. 1991. Infertility: A Tabulation of Available Data on Prevalence of Primary and Secondary Infertility. Geneva: WHO. 


\title{
"What About Us?" \\ Bringing Infertility into \\ Reproductive Health Care
}

\author{
by Bishakha Datta
}

Bhiwandi is like many new towns around the world-an industrial center to which poor villagers from other parts of the country migrate. Located about an hour outside Bombay, the primarily workingclass population of 50,000-together with residents in 70 neighboring villages - finds employment in the power looms, agriculture, and other industries.

Despite its proximity to Bombay, India's most cosmopolitan city, the cultural values in this area are predominantly rural. Although the settlers have left their homes behind, they have carried their traditional attitudes with them; central to these values is that of the role of a woman as wife, mother, and homemaker in her husband's family. A woman who does not bear a child, preferably a son, within two years of marriage holds little cultural value. ${ }^{1}$ In addition to the disappointment she and her husband feel at not having a wanted child, she often faces constant jibing from her in-laws, while her husband may be encouraged to abandon her and remarry. Although men are the source of an infertility problem about as often as women, ${ }^{2}$ typically, a husband's family will not consider that he may be infertile.

Often, a childless woman is stigmatized beyond her immediate household. She may not be allowed to hold a newborn relative or even participate in the child's naming ceremony. "She is called waanj (barren)" says Pravina Palaye, field organizer at Family Planning Association of India in Bhiwandi. "There is a superstition that if she touches a baby, the baby will die." One community survey in Andhra Pradesh state found that actual and anticipated rude comments at social functions forced many infertile married

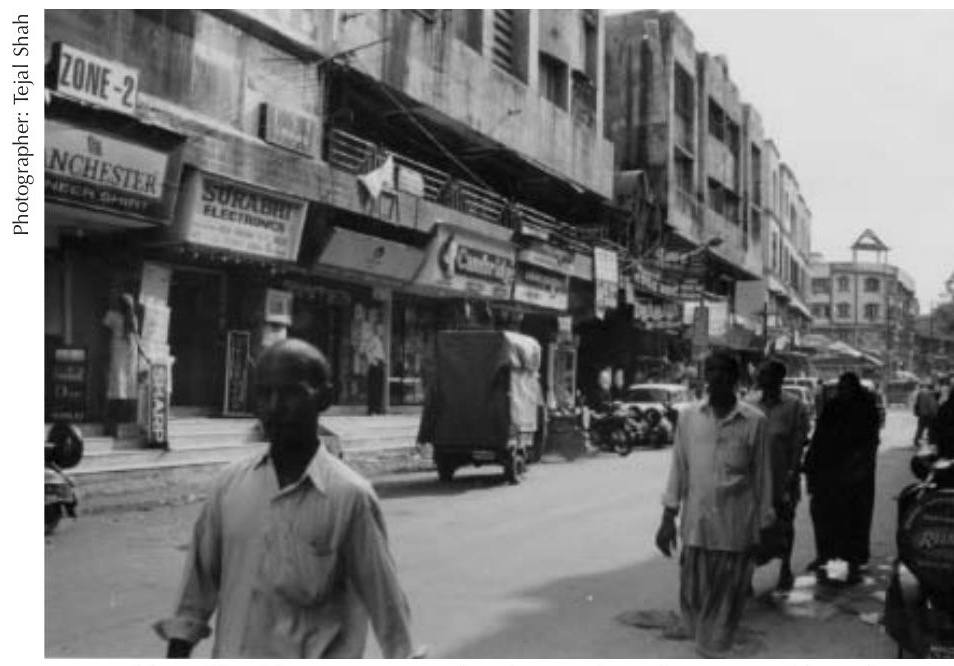

Many Bhiwandi residents are recent immigrants from the countryside and traditional values still shape family life. For example, a man whose wife does not bear a child may be encouraged to abandon her and remarry.

women into becoming social recluses, isolated and ashamed (Unisa 1999).

Such a predicament is not rare. About 10 percent of couples in India face infertility at some time in their lives, a figure consistent with the worldwide incidence

Indeed, women's health advocate Manisha Gupte has commented that "Having only daughters is ... seen as a form of childlessness. It's unbelievable, the layers of childlessness you can see in society."

2 Roughly one-third of infertility is related to a condition suffered by the female, about one-third is the result of a male condition, and one-third is of mixed origin. 
of infertility (Jeejeebhoy 1998). Yet there are few resources available to help infertile couples. Basic information (for example, about proper timing of intercourse or avoiding excessive heat to the scrotum) would help some couples, but there are few ways to acquire such information. For working-class people, clinical services for diagnosing and treating infertility are even more difficult to come by. ${ }^{3}$

In Bhiwandi, the public sector does not provide infertility care. Services in the private sector are not only of widely varying quality but also are well beyond the financial reach of most couples; nonetheless, where one's worth is measured by the birth of a child, women will go to extraordinary lengths in the effort to become parents. In desperation to conceive, some women resort to traditional approaches, including such painful ones as placing a heated brick on their bellies. Other women have fallen prey to unethical providers, as reported in a recent article in a Delhi newspaper:

In December 2000, the police arrested three doctors in southern India for cheating childless women, charging them exorbitant fees and making false claims about their pregnancy. The arrests took place after a woman, Sitamahalakshmi, lodged a police complaint about a doctor who had cheated her of $\$ 5,000$ by falsely claiming to have helped her conceive through an embryo transfer technique. Another woman, B Ratnakumari, filed a similar complaint against the same trio. Soon it became evident that this was a massive racket in which the three doctors had connived to dupe as many as 30 gullible women in the last three months alone. (The Pioneer 2000)
Neither have family planning programs responded to the needs of infertile couples. Reproductive health programs may seem like a logical "home" for addressing infertility, given the clear link between infertility, STIs, and basic reproductive health counseling. Despite this link and the enormous social consequences of involuntary childlessness, family planning programs have found it difficult to make the philosophical leap to devoting a measure of their limited resources to helping people reproduce.

The Family Planning Association of India (FPAI), an affiliate of the International Planned Parenthood Federation, has begun addressing the problem of infertility within a broad sexual and reproductive health mission. The town of Bhiwandi lies in the region covered by the Bombay branch of FPAI, and in 1996, FPAI launched one of its most important efforts there to provide services to infertile couples: the Comprehensive Reproductive Health for All project, or, in the Marathi language, Bahu Vyapak Prajanan Arogya Seva Sarvansathi Prakalp.

\section{The Family Planning Association of India}

FPAI, like many family planning organizations around the world, has made strides toward a comprehensive reproductive health framework since the 1994 International Conference on Population and Development held in Cairo. Yet the Comprehensive Reproductive Health for All project did not spring fully formed out of the Cairo agenda. Its seeds were sown in 1983 when FPAl started a women's development program in 70 villages in Bhiwandi District. Develop-

\footnotetext{
The community survey of infertile women reported by Unisa (1999) found that one-fourth of the respondents never sought help, for the most part because such help was too expensive (43 percent) or because they felt that it was unnecessary (41 percent). More than half of those who sought care had been through more than one course of treatment. The first choice of treatment was modern medical care (73 percent), although many women cut their treatment short because of cost; 63 percent also visited at least one holy place or spiritual healer.
} 
ment theorists had already highlighted the gender bias in community development programs, which generally focus on men, who are more visible within the community. "We found that within the rural integrated projects, men got the fruits of development, because men are freer, more educated, and nearer to power," notes Dr. Seshagiri Rao, who recently retired as secretary-general of FPAI.

\section{Mahila Mandals}

Working from the insight that empowering women can benefit the whole community and reduce family size, in 1983, the FPAI Women's Development program started setting up mahila mandals or village-level women's groups. Apart from teaching rural women about nutrition, hygiene, and safe delivery techniques, the mandal provided a rare opportunity for women to explore options beyond motherhood: literacy, incomegeneration, and the entirely alien notion of standing on one's own feet.

At first, few women responded positively. Those were the days when the Indian government was enforcing the slogan Hum do, hamare do ("We two, our two") through any means possible, including force. The fear of being sterilized was deep-rooted in the rural psyche, and the message of small family size was far removed from the realities of village life. Women would agree to come to a sterilization camp—but slip out through the back door when the time came. Men were openly dismissive. According to Pravina Palaye, Bhiwandi field organizer, the village men would ask the health workers, "If you operate on my wife, will you come and sleep with me? Will you come to look after my child?"

Over the years, the mandals built community trust and began successfully to address local politics, community development, the needs of young people, and other issues. Still, the reproductive health spotlight stayed focused on controlling population growth. The traditional bhajani mandals (groups that sing devotional songs) composed lyrics about family planning; newlyweds who agreed

\section{Despite the clear link between infertility, STIs, and basic repro- ductive health counseling, family planning programs have found it difficult to make the philosophical leap to devoting a measure of their limited resources to helping people reproduce.}

to use condoms or other spacing methods were publicly congratulated, as were those who voluntarily chose to be sterilized after having two children.

Infertility treatment was not a feature of this programmatic landscape. "Everything else [beyond the messages of small family size and women's empowerment] was a blind spot," says Dr. Rao. "We did not see it till we focused on it."

Childless women occasionally asked for help, but would be treated in an ad hoc manner. "We would regretfully say, 'We can't help you . . . why don't you think of adopting?'" says Pravina. She recalls that at one FPAI community celebration, a woman approached the FPAI health worker-and did some plain speaking. "You'll only do things for those who have children. What about us? Can't you do anything for those who don't have children?"

\section{From Family Planning to Sexual and Reproductive Health}

The 1994 International Conference on Population and Development had a significant impact on family planning programs in India. In the government program, longtime contraceptive quota and 


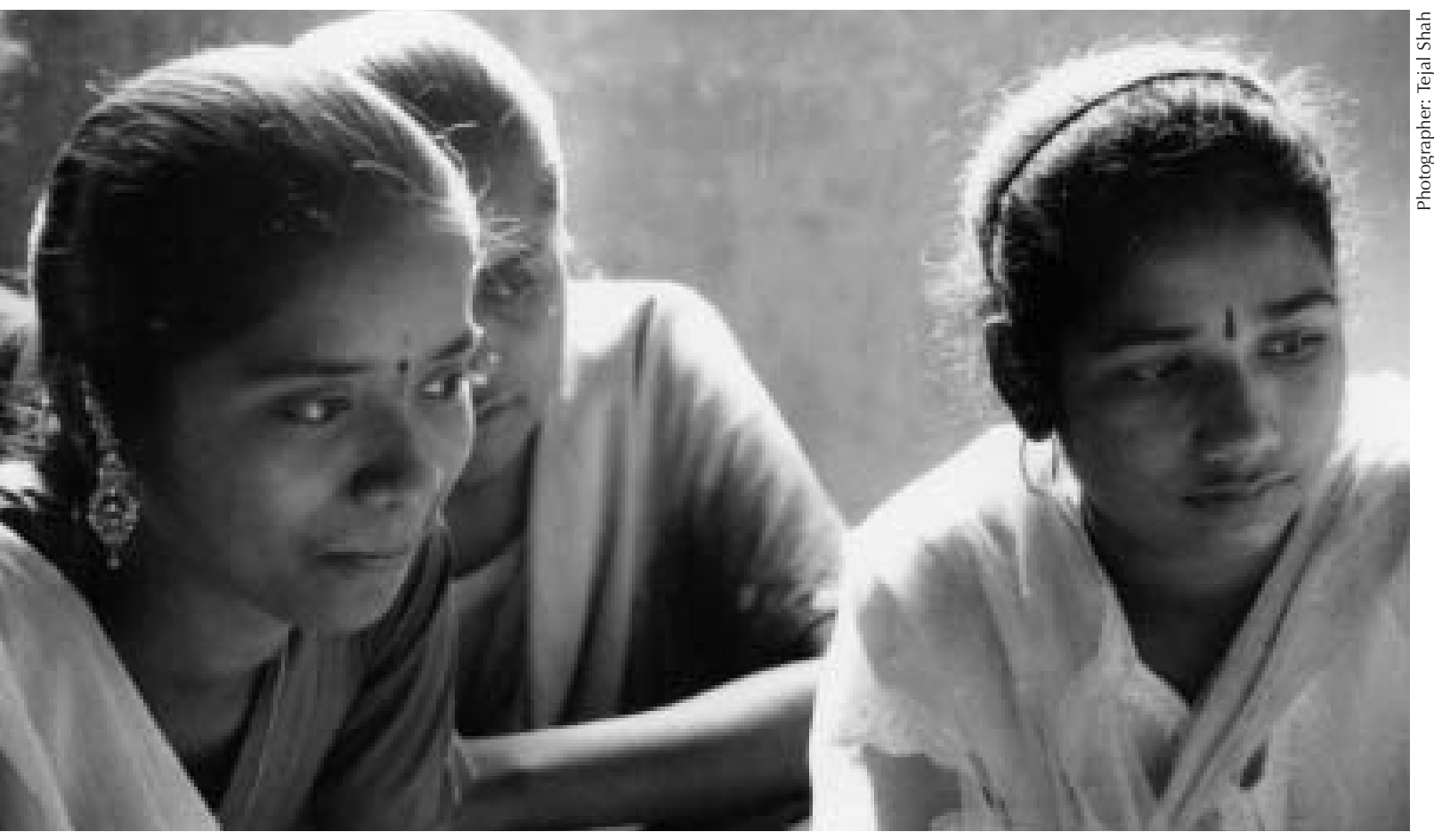

Despite the emotional pain and stigma associated with childlessness, infertile women who begged for assistance were, for decades, regretfully told that FPAI could not help. The ICPD and IPPF's Charter of Sexual and Reproductive Rights both paved the way for a more effective response.

incentive programs are gradually giving way to more voluntary schemes, and attention is being paid to ways that programs can effectively involve men as well as women (Patchauri 2001; Murthy et al. 2002). FPAl, which in 1994 had 43 clinics across the country, decided to implement the Cairo agenda in several areas, including Bhiwandi, where it already had a strong community-based program in place.

The International Planned Parenthood Foundation's new Charter of Sexual and Reproductive Rights provided a conceptual framework. The Charter identified a number of rights related to reproductive health care and has been used to reshape IPPF services in several countries. Some of its provisions have direct implications for infertile couples. For example, the "Right to the Benefits of Scientific Progress" states that "all persons shall have the benefit of and access to available reproductive health-care technology, including that related to infertil- ity, contraception, and abortion, where to withhold access to such technology would have harmful effects on health and well-being" (IPPF 1996). Other provisions in the Charter include the right to decide whether to found and plan a family, to decide whether or when to have children, and to have the highest possible quality of health care.

Introducing a new approach is always easier said than done. Although international guidelines existed, the institution had to develop and commit to its own institutional vision. Dr. Rao explains, "We didn't know what reproductive health was. It means everything and nothing. We felt whatever we were doing was reproductive health. We needed to change the mindset."

The institution faced both internal and external resistance. Dr. Sangameshwar Nagral is the President of the Bombay branch of FPAI, which officially sponsors the Bhiwandi clinic. Dr. Nagral, who began volunteering with FPAI dur- 
ing his student days 50 years ago, also serves as Vice President of the National FPAI Volunteer Board. He is currently active in promoting and supporting the Bhiwandi project, but admits that he was initially skeptical, partly because of the town's demographics: A majority of residents are migrants or Muslims, two groups that family planning programs have had difficulty reaching. "I was sure we would fail," says Dr. Nagral.

In addition, as Dr. Nagral explains, the town's private doctors as well as the Medical Association of Bhiwandi had strongly opposed the clinic. "The reason was very simple," he says. "There was fear among the professionals of losing money." External barriers such as these were negotiated through the support of eminent local persons, such as Professor Ganesh Gadre, chairman of the Bhiwandi project. To build support, the clinic offered contraceptive technology workshops for local doctors, and developed a plan to refer clients to them for services not offered at the clinic, in some cases at a reduced fee.

To design the new program, Dr. Rao, Dr. Nagral, and the Bhiwandi staff turned to the community. They conducted a community survey to identify unmet sexual and reproductive health needs and to determine the best ways to meet those needs. Infertility was among the highest priorities named.

\section{The Comprehensive} Reproductive Health For All Project

The survey results led to a plan for a combination of clinical and community services that would be, according to Dr.
Rao, "our most experimental, most comprehensive project." In 1996, with a three-year grant from the Ford Foundation and support from IPPF's South Asia regional office, FPAI launched its Comprehensive Reproductive Health For All project. Implementing the new program involved the following steps:

- Recruiting a new breed of staff. The project required a staff of 20. Many staff were recruited from within FPAI, but an effort was made to find personnel with open minds, or, as Dr. Rao notes, "without any family planning baggage."

- Training the entire team. The project's medical officer was sent to the Liverpool School of Tropical Hygiene for clinical training in reproductive health. In addition, all project staff were given training in various aspects of reproductive health, sexuality, and community participation.

- Fostering self-reflection and developing counseling skills, especially for sensitive topics like infertility and sexuality. "When the community is biased against infertile people, people serving them will also share the bias," explains Dr. Rao. "Many [new staff] were [also] hesitant to ask questions about sexuality. The training slowly dealt with these fears, which withered away."

- Setting norms and standards, especially in areas that were new to the organization, including infertility. ${ }^{5}$ To ensure that women would not automatically carry the blame for causing and the burden of resolving the problem of infertility, the organization established one overarching principle from the start: The couple, not the woman alone, must come for treatment.

\footnotetext{
${ }^{4}$ Since the start-up period, the clinic has conducted several follow-up trainings on reproductive health. For example, in 1997, FPAI provided one-to-two-day follow-up counseling workshops for all staff.

${ }_{5}^{5}$ Another such area was HIV testing and treatment. Initially, staff felt that inclusion of these services would deter other patients from coming to the clinic. FPAl's philosophy, however, focused on the rights of all clients, and ultimately, the clinic developed special norms regarding confidentiality and treatment.
} 


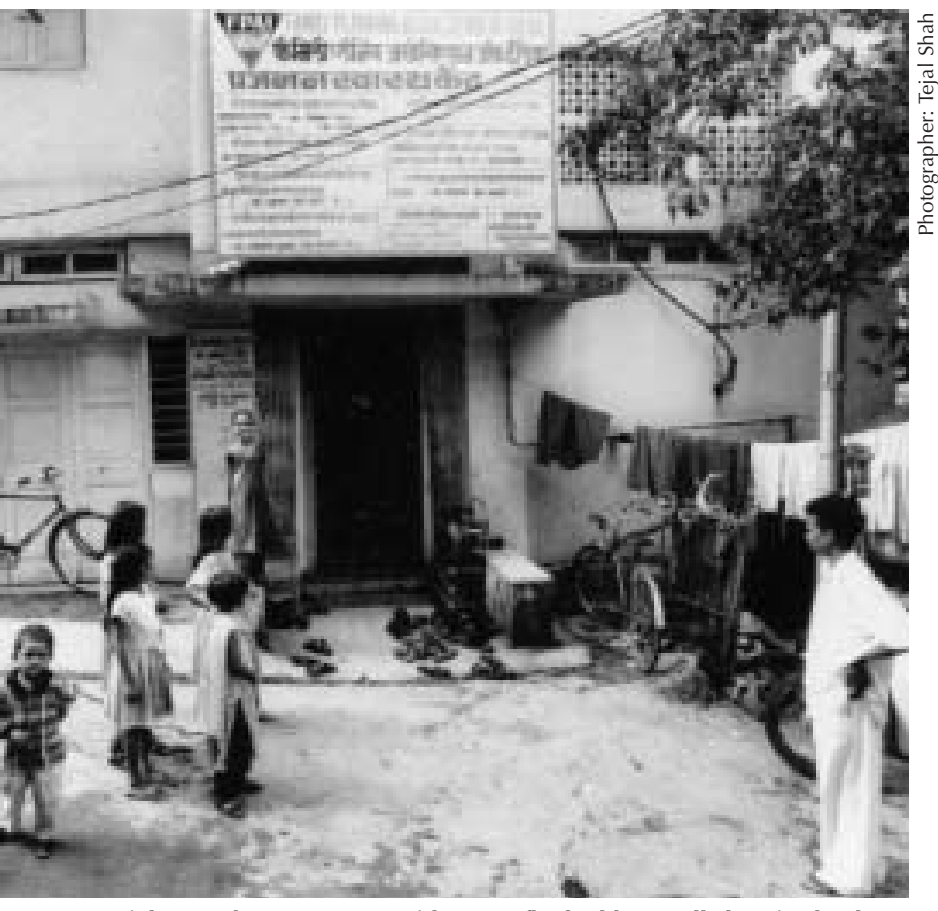

A quick turn down a narrow sidestreet flanked by small shanties leads to the FPAI clinic-a gray, two-story building with peeling paint.

In October of 1996, the Comprehensive Reproductive Health for All project began providing services. The clinic, which previously provided only family planning services, now offers a range of services under one roof, including gynecological checkups; antenatal care; firsttrimester abortion; cervical cancer screening; infertility treatment; contraception; diagnosis and treatment of STIs, reproductive tract infections, and HIV; and reproductive health counseling (the last four services are available for both men and women). For the most part, the services are organized into special clinics at designated times of the week. Infertility appointments are available on Wednesday and Friday mornings, although male infertility clients may also attend the general men's clinic on Friday afternoons.

The annual cost of operating the comprehensive reproductive health clinic is US\$27,880. Since the initial three-year grant from the Ford Foundation ended, IPPF pays for the clinic's personnel costs, which amount to 58 percent of the annual budget. The remaining 42 percent is met through contributions from the Bombay branch of FPAI (18 percent) and users (24 percent). The clinic collects fees for various clinical services (about ten cents for registration, \$12 for an abortion, and more for more complex procedures); for contraceptive methods; and for participating in skills-development workshops, such as beautician training.

\section{Overview of the Infertility Service}

My first visit is on a steamy Friday morning in May. The clinic-still popularly known as the mahila mandal clinic-is an arm's length from Bhiwandi's teeming marketplace, where slender minarets, colorful saris, and appetizing sweetmeats jostle for attention. A quick turn down a narrow sidestreet flanked by small shanties leads to the clinic-a gray, two-story building with peeling paint. Inside, several couples sit patiently on the wooden benches lining the waiting area.

Key staff in the infertility program include Dr. Kalyani Kelkar, a female gynecologist who sees the women, and Dr. Ajay Kanbur, an andrologist who treats the men. Dr. Kelkar worked as a general practitioner in a neighboring community and responded to an advertisement for the position. Dr. Kanbur was expressly interested in working with FPAI to shift its priorities to include men. He notes, "As an andrologist, I thought it would be interesting to be part of the first full-fledged male clinic in the FPAI system." Another key staff member is Pravina Palaye, who has been with the Bhiwandi program since it began, first as a typist and then a statistical assistant before becoming the field organizer.

From the first weeks of operation of the Comprehensive Reproductive Health 


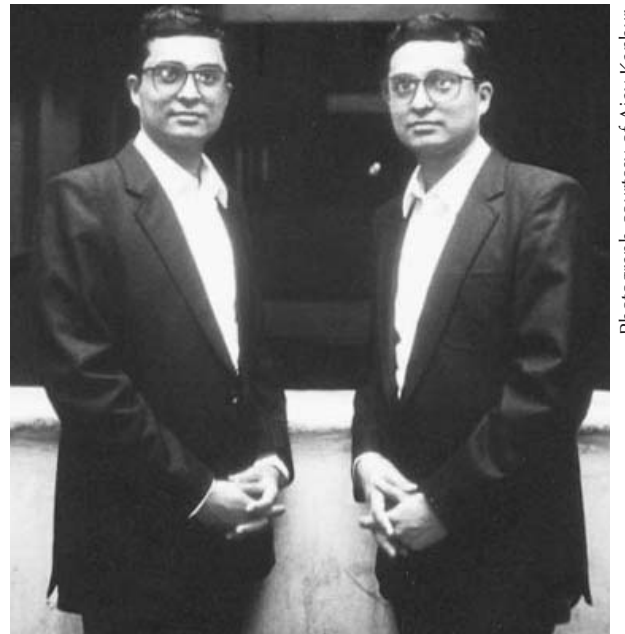

Ajay Kanbur treats men for infertility; his identical twin brother, Ajit, has also worked at the clinic performing sterilization procedures. Ajay explains, "Some clients did confuse us. Luckily, Ajit worked on a different day from me!"

for All project, childless women began seeking help. By the end of 2001, about five years later, 717 couples, ranging in age from 16 to 48, had sought infertility care at the clinic. Infertility clients now account for one-tenth of all clients at the Bhiwandi clinic. Seventy percent (502 couples) were cases of primary infertility, and the remainder (215 couples) were suffering from secondary infertility. One-third of all infertility cases are referred by clinic clients; outside doctors, field-workers, and government agencies are also major sources of referral. Roughly 25 percent of clients come from outside the project area. Close to a third of new clients have already tried their luck either with traditional healers, the public health system, or private practitioners.

\section{Focusing on the Couple, Not the Woman}

Two out of three women first seek help for infertility at the Bhiwandi clinic without their husbands. Staff conduct an initial exam for each woman and take her history whether she comes alone or with her husband. Although the man may be the infertile partner (or may have transmitted an infection to his wife that impaired her fertility), many men find it difficult to accept their role in infertility. Dr. Rao describes the despair of a husband who cannot impregnate his wife: "The man feels he is no longer a man."

The next step is to make a new appointment for the couple to return together for a joint counseling session, and a separate appointment for the man to begin his own screening and possible treatment, even if a woman's initial history indicates that she may be infertile. "We ensure that no man is left out," says Dr. Ajay Kanbur. "It's no use only investigating the female. Dr. Kelkar adds, "She has not come here to prove her fertility. They have come here for the baby. So both should come."

Only about five percent of husbands refuse to come in with their wives for infertility testing. In such cases, treatment usually grinds to a halt. "The dropout rate is much higher if there is no cooperation from the husband," explains Dr. Kelkar.

\section{Counseling and}

\section{History - taking}

Unisa (1999) describes infertility as carrying, at least in India, "more negative social, cultural and emotional repercussions for childless women than any other

\section{Given the tremendous anxiety typically associated with infertility, offering couples greater knowledge and emotional comfort is no small matter.}

non-life-threatening condition." Couples who arrive at an infertility clinic are typically experiencing a sense of failure, often with significant emotional stress, both within the couple and between the 


\section{What are the Basic Components of Infertility Counseling?}

Providing emotional support, for example:

Allowing clients to process their feelings (of shame, loss, fear, and hope)

Offering empathetic support

Balancing hope and realistic expectations

Offering accurate and useful information, for example:

Explaining how to identify the fertile time in the cycle

Providing clear descriptions of diagnoses or treatment options and likely outcomes

Enabling clients to make their own decisions, for example:

Whether to undertake certain procedures

When to accept childlessness and consider other options (for example, adoption)

Helping clients resolve conflicts, for example:

Anger toward or guilt on the part of the infertile person

Disagreement between partners about continuing treatment

Coping with pressures from extended family members

couple and the extended family. Furthermore, because diagnosis and treatment can take a long time and involve rising and falling hopes, the process of receiving care can deepen a couple's anxiety.

Nilima Mehta, a consultant and trainer who works with FPAI, comments, "Infertile couples usually come to a counselor with one single goal. To have a baby." Unfortunately, despite the best efforts of medical specialists, the majority of couples seeking infertility care will not achieve pregnancy. In light of that reality, the only concrete benefit that most infertility clients can realistically expect ultimately to take from their experience with infertility care is greater knowledge and emotional comfort. Given the tremendous anxiety typically associated with infertility, helping couples achieve greater psychological wellbeing is no small matter. Indeed, because emotional support is the one thing that providers can promise, high-quality counseling-something that does not require specialized medical training or costly equipment-is one of the most critical components of an infertility service.

Many family planning clinics and infertility centers have specialized coun- selors; in some settings, links are also available to infertility support groups where couples can share information and offer each other crucial emotional support (see box on Infertility Support Groups). At Bhiwandi, as Dr. Kelkar explains, "We don't have a separate, professionally trained counselor. But this does not mean there is no counseling. The staff sit with patients and talk to them. It is informal, done by many people. "

For infertility clients at the Bhiwandi clinic, the primary direct caregivers are physicians. As medical specialists, their job is to take detailed medical histories, provide health-related information, and concentrate on the complex medical maze of possible diagnoses and treatments that they are trained to consider. Not surprisingly, these considerable demands-along with time pressuresconstrain the possibilities for two-way, open-ended dialogue that characterizes true counseling and education. Nor are women routinely taught methods to confirm whether they are ovulating, or to identify the fertile time of the cycle. Instead, more emphasis is given to transmitting critical medical information. "Counseling" is largely subsumed with- 


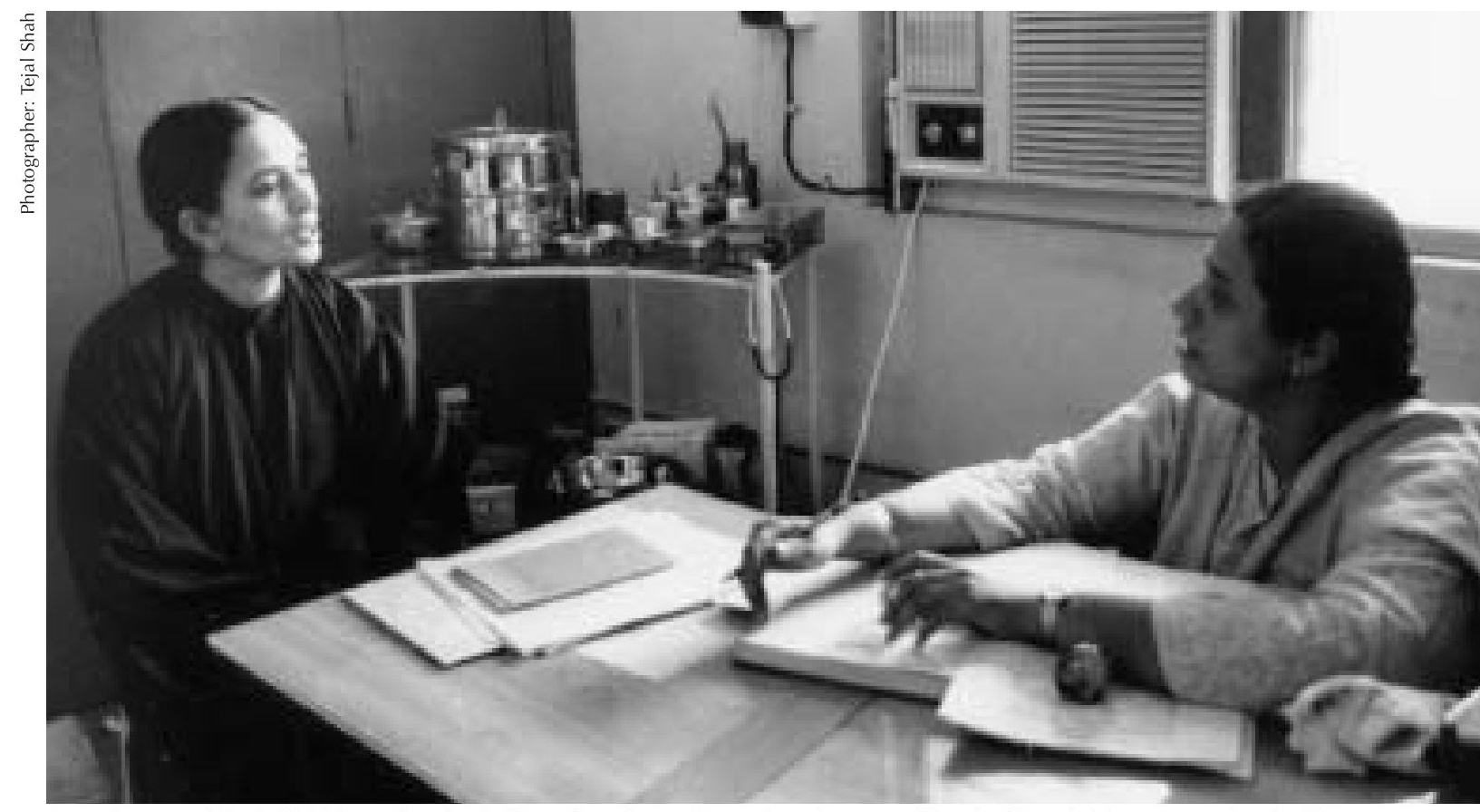

One element of the initial history is a frank discussion of sexual practices that may affect fertility. If either partner has had intercourse outside of marriage, follow-up includes testing for the presence or possible sequelae of an STI.

in the processes of taking a history, conducting follow-up interviews, and providing explanations and instructions.

Although significant strides remain to be made at Bhiwandi in attending to the emotional and educational needs of infertile couples, both Drs. Kelkar and Kanbur clearly provide information and support to their clients. This begins with communicating to the woman, and then

\section{Infertility Support Groups}

Locally based support groups enable infertile women and men to share information and personal experiences, thus increasing their understanding of their own situation and reducing their feelings of isolation and stigma. Such groups, which have proliferated in several Western countries, require virtually no financial resources.

In some countries, the local support groups are associated with national organizations, for example, CHILD in Great Britain and RESOLVE in the United States. In addition to providing an umbrella for the support groups, these organizations provide information and referrals (for example, for treatment or adoption) through hot lines and websites. They also lobby for expanded access to medical services and promote public awareness of the impact and extent of infertility.

Support groups may take different shapes and can be formal or informal gatherings. One published report (Anonymous 1999) about a RESOLVE group described the "strong emotional impact" of the experience, in terms of the support received by those individuals wanting to pursue further treatments as well as for those who "were helped to come to terms with the fact that although technology gives hope, hope is not always realistic."

Contact information for CHILD and RESOLVE: CHILD e-mail: office@child.org.uk; http://www.child.org.uk/. RESOLVE e-mail: info@resolve.org; http://www.resolve.org. 
to her husband and to the extended family, the importance of the man's coming in for screening and treatment.

The doctors also try to establish a comfortable atmosphere so that the client can provide a detailed history without embarrassment. The medical history is taken separately for the wife and the husband. Along with inquiries about previous pregnancies, infections, and sexual patterns, the staff also ask about contraceptive history, because occasionally one member of a couple hopes to reverse a sterilization. The history form for men also includes questions about the respondent's occupation, because many industrial workers are exposed to high temperatures, which may affect spermatogenesis.

Another critical element of the initial history and counseling is a frank discussion of sexual practices that may affect fertility. In speaking with a man, for example, Dr. Kanbur explains, "We ask him how often he has sex-either with someone or by masturbation, to learn whether he is discharging semen." In the session with a woman, she is asked about when during her menstrual cycle sex takes place, and about sexual dysfunction. ${ }^{6}$ Dr. Kelkar adds, "We ask women if they or their husbands have a history of intercourse outside marriage." Even for clients who do not report diagnosed STIs, a "yes" is taken as an indication of vulnerability to STIs. Because of the importance of STIs as a risk factor for infertility, the clinic tests all male clients and those females who have a white cervical discharge or who are considered vulnerable.

Although the clinic does not routinely teach women methods of fertility awareness, Dr. Kelkar provides such information to selected women. She explains, for example, that if a couple is having intercourse infrequently, it is unlikely that intercourse is coinciding with the exact period of ovulation. In such cases, she advises the woman regarding the likely fertile time of her cycle and advises her to "have relations" during that period.

Another challenging task is helping clients understand that the process of diagnosis and treatment is a slow one. Dr. Kelkar explains, "Many clients think they will have only one visit, take medicine, and have a child. According to Sundeep Kadam, a community health worker with the project, male clients are particularly impatient. He explains, "If they don't get results, they change doctors very quickly." The staff instruct the clients from the outset about the extended period that treatment may require. At the same time, they offer hope and reassurance.

For those couples who are experiencing stress from extended diagnosis and treatment, talking can sometimes help. As Dr. Kelkar comments, "The couple's life becomes dominated by temperature charts, blood tests, and endless waiting in clinics. We have to deal with it."

Nilima Mehta provides occasional refresher training to FPAI staff. She reminds staff that counseling is an enabling process that helps couples or individuals make their own decisions, and emphasizes that "counselors have to step in at a stage where medical technology fails and other options have to be looked at."

\section{Diagnosing and Treating Men for Infertility}

The Bhiwandi clinic has a special reproductive health clinic for men that operates on Friday afternoons when the power loom factories are closed. Although

\footnotetext{
${ }^{6}$ For a small number of couples, certain psychosexual problems preclude intercourse; for example, a man may suffer erectile dysfunction (often treatable with Viagra). Also, in parts of India, men may be concerned that semen loss may lead to infertility.
} 
the men's clinic offers other services, such as STI testing and condom distribution, 80 percent of the men who come through the door are seeking infertility treatment. ${ }^{7}$

Dr. Kanbur is assisted by two male community welfare workers, Sundeep Kadam and B.Y. Yadav. Both have been with FPAI for more than 15 years, and were recruited into this project when it was felt that men were better able to talk to other men about their reproductive and sexual health problems. Sundeep and B.Y. are primarily responsible for providing basic education and referrals to men in the community, while Dr. Kanbur counsels the men in the clinic. The basic infertility work-up for men, which costs about 60 percent of the fee for the same services provided in the private sector, includes:

- screening for gonorrhea, syphilis, chlamydia, and HIV

- two semen analyses, examining number, morphology, and motility of sperm, and quality of sperm interaction

- blood tests for testosterone levels

- a physical exam, with attention to screening for varicocoeles or anatomical abnormalities (such as undescended testicle).

For the vast majority of cases (65 percent), staff are not able to identify any cause of infertility. In part, this is because access to costly diagnostic techniques is inadequate. In any case, diagnosis is a universal challenge in infertility treatment, regardless of cost. Among the 35 percent who are clearly diagnosed, the husband is more often identified as the infertile partner. The leading cause of male infertility at the clinic is oligospermia, defined as fewer than 20 million sperm per $\mathrm{ml}$. Even among those men with a diagnosed problem, treatment effectively raises sperm counts for only about 20 percent (see box on Low Sperm Counts).

\section{Helping Men}

\section{Acknowledge Their Own Fertility Problem}

Just because a woman has convinced her husband to come to the clinic, his readiness to accept his own potential infertility is not guaranteed. According to Dr. Kanbur, "The Indian male ego is problem number one. Men do not want to take responsibility for this. It is difficult for a man to believe that he is infertile." He describes the typical male reaction as one of "hurt, shock, denial, and remarriage." Sadly, some men face their own infertility only after they have already abandoned their first wives and remarried. Explains Dr. Kanbur, "When that (strategy) also fails, they know something is wrong." To avoid this reaction and help a man acknowledge his role in childlessness, Dr. Kanbur insists that his wife be present when they discuss his treatment.

\section{Using Donor Sperm}

The Bhiwandi clinic offers artificial insemination, using semen samples from
The clinic offers artificial insemination, but some men do not want even their wives to know the sperm is not their own. Dr. Kanbur explains, "The woman must know. Otherwise, we can't impregnate her."

\footnotetext{
7 Those who come for other reasons often want to be tested for STIs or have semen-related problems. Because many of the men attending the clinic are migrant workers who frequent the red-light district, the clinic routinely seeks their consent to test for gonorrhea, chlamydia, and HIV.
} 


\section{Low Sperm Counts}

Worldwide, low sperm counts are a major factor in male infertility. Dr. Kanbur explains, "Excess heat to the testicles is the big culprit. A rise in testicular temperature by even one degree Fahrenheit can reduce sperm count." One of the most common causes of elevated testicular temperature is environmental heat. Many men in Bhiwandi work in factory jobs involving furnaces or ovens; furthermore, they are "overdressed" in underwear, pants, and factory overalls. Dr. Kanbur asks some clients "to take a cold water bath every day, or dip (their) testes in a mug of cold water, to undress when (they go) to sleep. He says, "Sometimes I even ask them to move temporarily to a cooler job."

Testicular temperature may also be elevated as a result of a varicocoele, a condition in which drainage from the scrotal veins is poor, generally associated with a varicosity. According to Walsh et al. (1992), varicocoele is responsible for about 10 percent of male infertility worldwide. This condition can often be corrected surgically, and Dr. Kanbur performs varicocoele operations at the clinic. The operation takes about an hour and is performed under spinal anesthesia. The clinic charges about Rs 4,000 (US \$90), including surgery, a night's stay, and anesthesia.

Less common causes of thermal oligospermia (both globally and at the clinic) include:

- Infection leading to hydrocoele (a reversible condition in which accumulation of water in the scrotum leads to excess warmth and physical pressure on the testes.

- Anatomical abnormalities such as undescended testicles

- Tobacco and alcohol use

- Low testosterone (sometimes treated at the clinic with synthetic testosterone)

- Blockage in the vas deferens (for which the clinic refers the client to another facility for corrective surgery)

Unfortunately, often oligospermia has no clear origin. Therefore, along with the specific treatment options mentioned above, the staff suggest several general approaches to improving sperm counts:

- extending intervals between ejaculations to allow sperm counts to build up;

- sperm washing (used when the sperm are of low volume but have good motility), a technique in which sperm are collected, undergo a "wash" that separates healthy sperm, which are injected directly into the woman's uterus; and

- referrals for more sophisticated treatments, such as testicular sperm aspiration and sperm autopreservation. Autopreservation (essentially capturing and freezing repeated semen samples) may be useful in cases when the husband is separated from his spouse for long periods.

a local private clinic. The samples cost $\$ 17$ each. Most of the clinic's infertility clients, however, give priority to reproducing with their own sperm. Before trying artificial insemination with donor sperm, they will pay for various costly techniques that use their own sperm. Says Dr. Kanbur, "If that doesn't work, then they'll go for donor sperm."
Even those men who elect to use donor sperm tend to experience shame, and a few men do not want even their wives to know that another man's sperm are being used. As Dr. Kanbur explains, the doctor must help the man confront this delicate situation. "As an andrologist, I feel the woman must know. We get her consent. Otherwise, we can't impregnate her." 


\section{Diagnosing and Treating Women}

Women's bodies perform a stream of functions related to reproduction. Among these functions are ovulation, fostering the penetration of sperm through the cervical mucus and opening, transporting a fertilized egg through the fallopian tube, implanting the egg in the endometrium, and continuing maintenance of the embryo and fetus. Infertility can result from a difficulty with any of these functions. The basic infertility work-up for women includes:

- a physical and gynecological exam;

- a cervical mucus study;

- tests for RTIs and STIs where infection is suspected;

- endometrial histopathology where pelvic tuberculosis is suspected; and

- blood tests for hormone levels as well as for infections that could lead to miscarriage.
As with the services for men, the fees for screening and treating women for infertility are far lower than those charged in the private sector. For example, an initial consultation at a private doctor's office costs about 200 rupees, compared with 30 rupees (about 10 cents) at the clinic. Basic laboratory tests cost close to $\$ 2$ privately, almost twice the price at FPAI. The biggest cost difference, however, is for surgical procedures: 3,500 rupees is charged in the private sector compared with 1,500 rupees at the project.

Some diagnostic tests, however, remain beyond the financial reach of many clients. For example, although a client may have a tubal blockage initially diagnosed through laparoscopy, a hysterosalpingram may be needed to confirm the diagnosis. Similarly, ultrasound may be required to confirm ovulation. Therefore, a greater prevalence of tubal blockage may exist among female clients than the staff can diagnose definitively. In large part because the clinic lacks more sophisticated

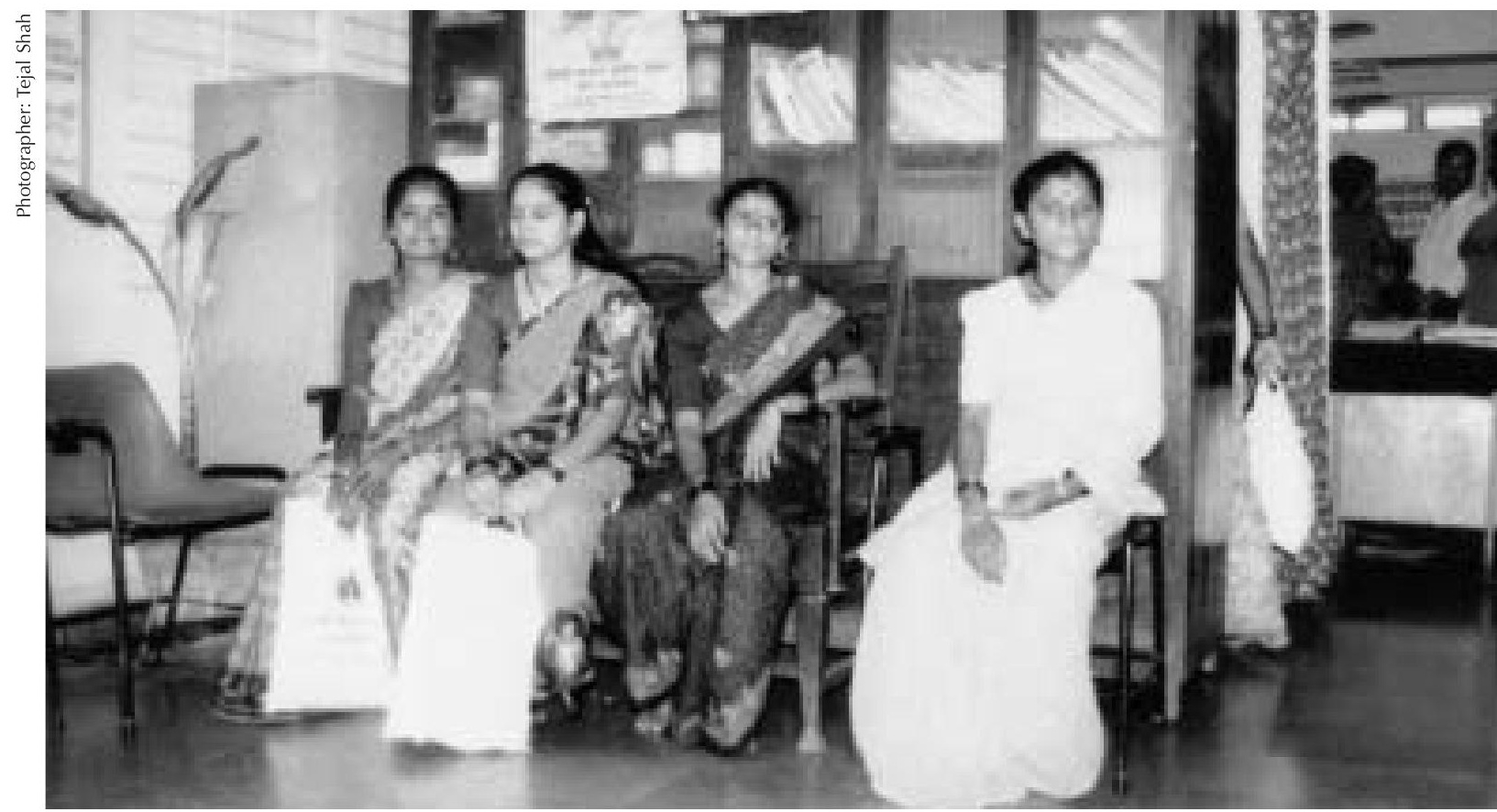

Infertile women typically experience a sense of shame and failure, and most couples are willing to pay for services in the hopes of having a child. At the Bhiwandi clinic, infertility accounts for 10 percent of the client load. 


\section{Tuberculosis and Infertility}

Although endometrial-or pelvictuberculosis is rare in developed countries, it is fairly common in many developing countries, and particularly in India, where approximately 10 percent of women with pulmonary TB (or tubercular lesions in other sites) develop lesions in the reproductive tract. Pelvic tuberculosis is often a silent disease, present for 10 to 20 years within women who remain in apparent excellent health. Infertility may be one of the few symptoms of the disease, and sometimes the only reason the woman is ever tested for TB.

Infertililty secondary to pelvic TB is not rare. According to one study, pelvic TB occurs in about 6 percent of cases of infertility among Indian women (Dawn 1995). Another study conducted in India showed that of 300 women with tubal infertility, 39 percent had pelvic tuberculosis, either currently or in the past (Parikh et al. 1997).

At the Bhiwandi clinic, pelvic TB may be noted initially during a diagnostic laparoscopy. A sample of endometrial tissue is taken by dilitation and curettage and sent for a histopathology test. Although antituberculin drugs can cure the underlying infection, the tubal or endometrial scarring leaves women with little chance of becoming pregnant; overall, only 5 percent of women with infertility related to pelvic tuberculosis ultimately conceive (SIRM 2002). technology, only 7 percent of the infertility cases at the Bhiwandi clinic are diagnosed as the result of a specific condition suffered by the woman.

Among cases for which a definitive female diagnosis is possible, the most common causes of infertility are nonovulatory cycles due to hormonal imbalances and tubal or endometrial scarring from infection. Most commonly, pelvic infections are the result of an STI (such as chlamydia or gonorrhea), unsafe abortion, or tuberculosis. (see box on Tuberculosis and Infertility). ${ }^{8}$

The Bhiwandi staff are able to treat some conditions of female infertility directly. For example:

- Women with endocrine problems may be treated with fertility drugs to promote ovulation. Typically, women are given clomifen citrate.

- In cases where the vaginal or cervical environment appears unreceptive to sperm, the woman may be inseminated intracervically.

- Laparoscopy is performed when a uterine, tubal, or ovarian abnormality is suspected that can be visually diagnosed. Dilitation and curettage is also performed if indicated.

Other treatments for female infertility are often more expensive and invasive, and require referral to another provider. For women who have been diagnosed with blocked tubes, and the site of the blockage has been identified by hysterosalpingogram, the staff refer the client to another FPAI facility in Bombay for surgery to resection the tubes. ${ }^{9}$

\footnotetext{
${ }^{8}$ Worldwide, hormonal or endocrine disturbances account for 35 percent of infertility among women; tubal factors account for 32 percent; and acquired nontubal factors (such as endometrial tuberculosis) account for 12 percent. Less than 2 percent of female infertility is the result of sexual dysfunction or congenital abnormalities. The figures are similar for Asia (Jeejeebhoy 1998).

${ }^{9}$ Because the scarring and blockage from tuberculosis is usually more serious than that which is secondary to an STI, women with pelvic TB are not usually candidates for tuboplasty. Cases of active endometrial tuberculosis are sent to tuberculosis treatment centers in the municipal hospital.
} 
Some of the women who continue to have ovulatory problems or blocked tubes are candidates for more sophisticated artificial reproduction technologies, and are ultimately referred to larger infertility centers. In India today, an infertile couple theoretically has recourse to a vast array of assisted-conception technologies, from first-generation technologies such as in vitro fertilization (IVF) to newer ones such as gamete intrafallopian transfer (GIFT) and zygote intrafallopian transfer (ZIFT). ${ }^{10}$ "Whatever has come to the world has come to India," says Dr. Kanbur. Of course, Dr. Kanbur is painfully aware that wealth has not come to most of his clients, and that for the most part, those couples who seek these treatment go into debt to do so. He and Dr. Kelkar have referred about 25 couples for more sophisticated treatments, but they have not been able to follow them to determine how many became pregnant.

\section{Dealing with Repeat Miscarriages}

Among those women who can conceive but suffer repeat first-trimester miscarriage, the problem may stem from various conditions, including endocrine imbalance or infection. The four pathogens chiefly responsible for early miscarriage are known as TORCH: toxoplasma, rubella, cytomegalli, and herpes. The clinic can diagnose the presence of these underlying infections; in the case of toxoplasma, the underlying infection can be cured. A woman who has suffered repeat second-trimester miscarriages may have cervical impatency, in which the cervix dilates prematurely. In such a case, the clinic refers the client to another center where her cervix can be stitched early during pregnancy in the attempt to avoid a repeat loss.

\section{Case Studies}

Some cases are easily diagnosed and treated, such as that of Vijay and Kalyani Gawli:

Kalyani had become pregnant twice but miscarried both times within the first trimester. She and Vijay went to a private clinic, which charged them Rs.1,500 (US\$32) for each treatment, a significant expense for a couple relying on Vijay's salary from operating a tractor compression machine. The treatment failed. Adding to their dismay was the way the nurses treated them. Vijay reported, "They told my wife, 'You can't hold the baby, so what is the use of trying to conceive?'"

On the recommendation of a project field-worker who lives nearby, Kalyani and Vijay visited the Bhiwandi clinic, although they live almost 50 kilometers away. At Bhiwandi, a blood test showed that Kalyani had toxoplasmosis, an infection that can be caused by the proximity to animals. The clinic prescribed rovamycin, a medication unrelated to what had been prescribed at the private clinic. Within a short time, Kalyani became pregnant again and was able to carry the pregnancy to term. Kalyani and Vijay are the proud parents of two year-old Yash, whose name means "success."

\footnotetext{
${ }^{10}$ In IVF, the eggs and sperm are left together in an incubator for about 18 hours, then checked for fertilization and further embryonic development. The embryos are then placed in the uterus. In standard GIFT, laparoscopy is required to place three to six eggs, together with prepared sperm, in the end of the fallopian tubes. Fertilization then occurs in the fallopian tubes naturally. ZIFT is a method of assisted reproduction in which the woman's eggs are fertilized in the laboratory using the husband's sperm and are then placed in the fallopian tubes.
} 
Some cases are fairly easy to diagnose, but it is not always clear whether the treatment will be successful, as was the case for Vinod and Ashok, two male clients:

During the nine years Vinod and his wife had failed to conceive, they had experienced numerous unsuccessful encounters with private doctors. Then Vinod heard about the Bhiwandi clinic from a relative. When he first visited the clinic, his sperm count was 9 million $/ \mathrm{ml}$, well below the 20 million generally considered the minimum for conception. Upon physical examination, Dr. Kanbur diagnosed a varicocoele, and in mid-2000, Vinod underwent surgery to repair the varicocoele. In the first year after his surgery, his sperm count rose to 16 million, but his wife still did not become pregnant. At that time, Vinod explained, "At least there is hope. In other places, they didn't tell us what the problem is, but here they tell us. That's why I continue coming here."(The following year, Vinod's wife finally conceived.)

Ashok, 40 years old, had difficulty achieving an erection and was unable to ejaculate. After nine years of marriage, his wife had not become pregnant. At the clinic, Ashok was found to have a blockage in the ejaculatory duct. Dr. Kanbur performed endoscopic surgery to remove the obstruction. Although Ashok's sperm count rose, he was still unable to ejaculate during intercourse and was referred to another center for treatment, where his semen is being procured for artificial insemination.

Other cases are relatively simple to diagnose from a medical perspective, but difficult to treat because of male resistance:
Balram and Bhavna Sambre belong to a tribal community 22 kilometers from Bhiwandi. When Bhayna did not become pregnant after two years, the couple suffered ridicule from friends and relatives. Balram's mother heard about the Bhiwandi infertility clinic from her mahila mandal, then told her son, and the two of them sent Bhayna for treatment. Staff at the clinic told Bhayna that her husband must also be tested, but Balram refused, insisting that if anything was wrong, it would be with his wife. His mother agreed vehemently that infertility is a woman's problem. Finally, the president of the local mahila mandal met with both Balram and his mother, practically coercing them to come with her and Bhayna to the clinic for Balram to be tested.

At the clinic, Balram was diagnosed with both urinary and reproductive tract infections, as well as a low semen count. (Bhavna also had an RTI, but her cervical mucus and endometrial lining appeared normal.) Although staff had to contact them to continue treatment, their infections were eventually cured and Balram's semen count increased. Within a year, Bhayna conceived. The couple has now referred others for infertility care at the Bhiwandi clinic.

\section{The Bottom Line:} Becoming Pregnant

Unfortunately, the greatest number of cases are resolved not by conception, but by a couple's acceptance of their inability to reproduce. This outcome is common throughout the world, particularly where resources for more advanced diagnostic and therapeutic technologies are scarce. 
At the Bhiwandi clinic, among the 717 couples who began treatment between 1996 and 2001, 75 women (11 percent) successfully conceived, of whom five miscarried. Interestingly, success rates are almost the same among couples who had previously sought help elsewhere as among those who first sought care at the Bhiwandi clinic. No follow-up information is available concerning the outcome of the 25 couples who were considered candidates for more sophisticated infertility techniques and referred to centers in Bombay.

\section{Access to New}

Technologies

Dr. Kanbur feels strongly that the success rate at the Bhiwandi clinic is constrained primarily by lack of access to more advanced reproduction technolo- gies. He is able, currently, to treat only 20 percent of his male patients successfully; with better technology, around 40 percent of men could be treated, he asserts. The clinic faces a similar constraint on treatment for women.

Dr. Kanbur believes such technologies must be available at all infertility treatment centers. Of course, many of the couples who attend the Bhiwandi clinic are not able to pay for such expensive new approaches as in vitro fertilization and egg donation. Nor does the Bombay branch of FPAI have such resources. Dr. Kanbur deals month in and month out with couples who cannot conceive, and he believes that many treatments should be provided at least at subsidized rates. "Patients must have an equal right to all modes of treatment, regardless of their income status," he argues. "Let's get it done."

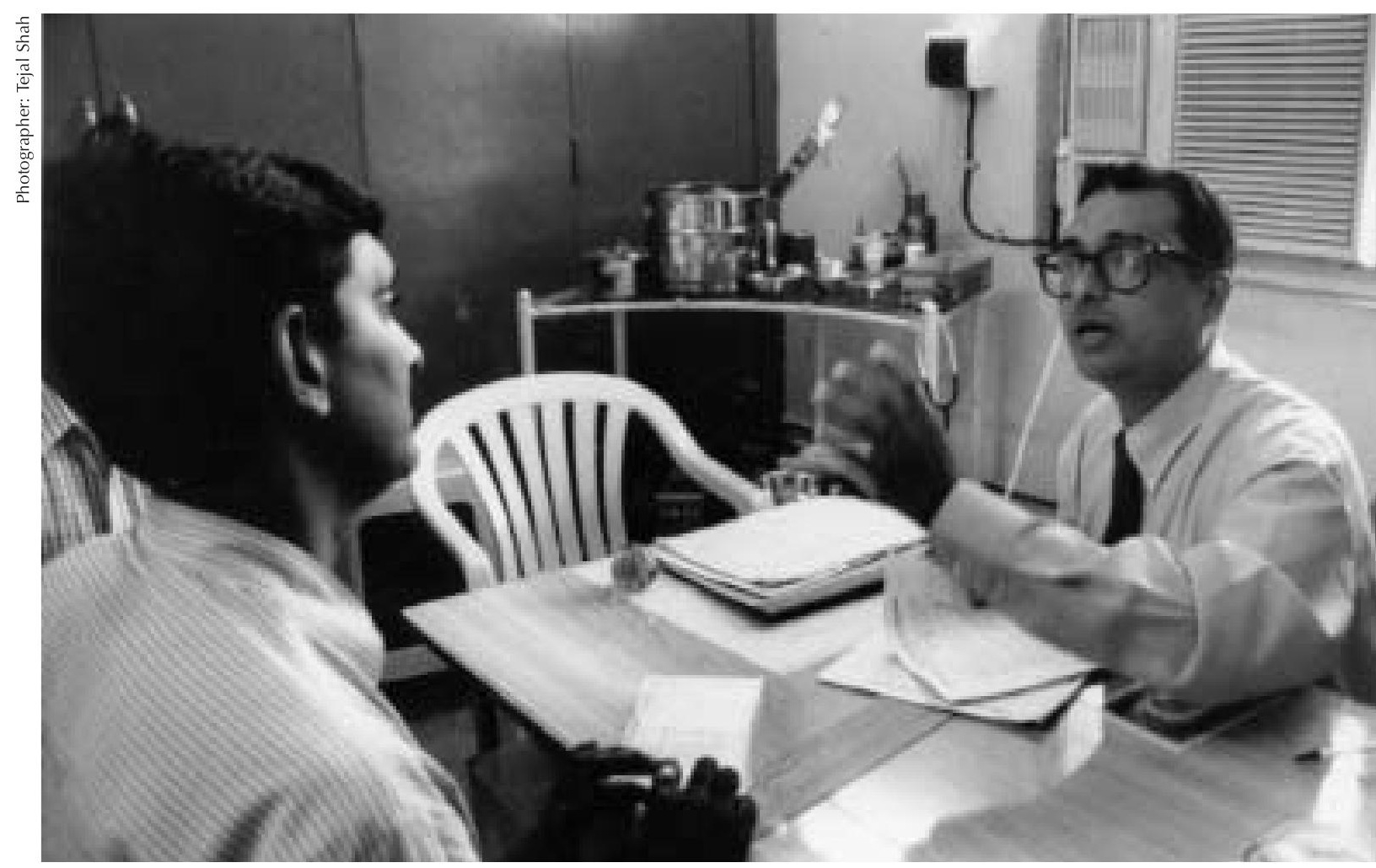

Dr. Kanbur believes reproductive technologies must be available at all infertility treatment centers, provided at subsidized rates. "Patients must have an equal right to all modes of treatment, regardless of their income status," he argues. 


\section{Helping Clients Resolve Ongoing Infertility}

Although the success stories are a source of great joy for staff as well as for their clients, to date, the vast majority of the couples who come to Bhiwandi have been unable to conceive. The staff must support clients through the difficult decision of whether and when to give up hope. Inevitably, the staff find

\section{The biggest challenge in reducing} infertility is to prevent it as

much as is possible, and that

means preventing the infections

that can impair fertility.

themselves advising those couples for whom treatment-even costly and invasive procedures in some cases-has not been successful. Dr. Kanbur sums up this difficult situation in a straightforward manner: "At some point we counsel the patients that the treatment is not working. Usually this is at a point when their finances or patience runs out, since this is a slow, long process."

Mahesh and Sandhya Kumwear live in a Bhiwandi slum area. They had been married for three years without having children. Mahesh had had a bilateral hernia operation. His semen analysis indicated zero sperm, and a subsequent vasography indicated that both vas deferens were totally blocked. The staff at Bhiwandi told the couple that they would not be able to conceive, but in Bombay they were informed that the blockage could be removed surgically. However, the surgery was expensive and success was not certain. Over the course of five counseling sessions back at the Bhiwandi clinic, during which staff offered consolation, suggested adoption (which Mahesh and Sandhya did not choose), and listened, the couple slowly began to cope with losing hope of having a child.

FPAI adoption consultant Nilima Mehta describes the emotional challenge for clients at this stage. "The final reconciliation with childlessness comes as a total shock to most individuals. 'No, this cannot be me,' is the first response. This slowly gives way to selfpity and anger: 'Why me?', followed by acceptance." In most developing countries, no community-based infertility support groups such as RESOLVE (described above), exist but Mehta trains FPAl staff to help. She says, "At this moment we can orient them toward looking at adoption as an option" (see box on adoption).

\section{Preventing}

\section{Infertility:}

Educating the

\section{Community about STIS}

The biggest challenge in reducing infertility is to prevent it as much as is possible, and that means preventing the infections that can impair fertility. At the Comprehensive Reproductive Health for All project, STI prevention is part of both clinical and community-awareness activities. In addition to diagnosing and treating STIs in the clinic (including routine voluntary testing of every man who comes through the doors), community workers conduct educational sessions on various reproductive health topics, including STIs.

Sundeep Kadam and B.Y. Yadav coordinate the community component of the Comprehensive Reproductive Health for 


\section{Adopting as an Alternative to Childlessness}

Infertile couples at the Bhiwandi clinic, and indeed throughout India, generally do not seek to adopt. Usually, they will try costly infertility treatments first. Only when such methods fail is adoption considered. "It's the last straw," says Dr. Kanbur. "If nothing else works."

The resistance to adoption is partly a response to legal factors. First, no uniform law on adoption is in effect in India; each religious community is governed by its own specific laws in this matter. Although Hindus are allowed to adopt, the laws of most other religious communities in India disallow or discourage official adoption. Hence, many Indians can act only as legal guardians to their adoptive children, who are granted the status of wards.

Bureaucratic obstacles are another inhibiting factor. Couples who are legally eligible to adopt are usually required to make a formal written application, followed by interviews and home visits. They must provide birth certificates, medical reports, recommendations, and extensive documentation of their finances; couples who just scrape through the income requirement must place a fixed deposit in the child's name to ensure financial security. The whole process takes close to a year to complete. "This can, in practical terms, make it difficult to adopt," says Nilima Mehta understatedly, "even though every family theoretically has a right to parenthood."

Finally, a key factor hindering adoption is cultural. Dr. Kelkar explains that many infertile couples don't want to adopt out of a "fear of society." Part of the stigma surrounding adoption arises because of class differences-adoptive parents tend to be more affluent, while adoptees are typically from poor families or orphanages. The stigma also may be partly a projection of the couple's unresolved frustration with their inability to conceive. Says Mehta, "Couples tend to believe that blood ties are superior to the ties of love. Socialization makes us believe that there is a deep bond with the umbilical cord. So people want to go through the physical process of giving birth." For this reason, Mehta seeks to ensure that couples resolve emotional issues related to their infertility before adopting.

In recent years, a trend has grown toward informal, noninstitutionalized adoption: A couple will hand over one of their children to a childless couple in their extended family. This phenomenon is common in cities and villages and is so much part of the Indian social landscape that it is not really considered adoption.

According to Nilima Mehta, attitudes are slowly changing: More Indian families are adopting children formally, and the shame associated with adoption is gradually fading. Dr. Kelkar remembers one infertile couple adopting an infant girl. The clinic maintains a list of adoption centers, to which couples are referred based on their income level.

All project. "We teach men about everything related to reproductive health," says B.Y., "from the importance of using condoms to the need to test themselves for STIs_and about infertility. These are all delicate issues, but we have to tell them. After all, it takes two hands to clap, it takes two people to have relations." Dr. Kanbur adds, "Although infertility is a devastating fate in the society, most people know almost nothing about causes or treatment options. Public awareness is zero." Providing information helps couples identify their own need for clinical follow-up.

We drive through lush rice fields to a community sexuality education workshop for girls. The women are bent over in the fields, sowing paddy in square patches of iridescent green. The road 
ends at Parivali, a small village, where 25 teenage girls have assembled in the village nursery school to meet with the Bhiwandi staff. This workshop grew out of suggestions from the male health worker and the mahila mandal. "Community awareness is created via the mahila mandals," says Virupax Rannebennur, FPAI's research and evaluation officer, "using articulate women leaders as change agents."

It is an afternoon of learning, punctuated by shocked giggles and embarrassed smiles. Most of these girls are not sent to school anymore. "If you sit at home, what do your parents do?" asks health worker Sunanda Gawli. "Get us married off," is the overwhelming consensus.

\section{The Importance of Addressing Gender Equity}

Technical information alone will make hardly a dent in infection rates, or, for that matter, in many other sexual and reproductive health outcomes. Achieving better outcomes will also require forging new, more equitable sexual and personal relationships between males and females, which will in turn make girls and women less vulnerable to unprotected or unwanted sex. Therefore, in addition to providing information about topics such as STIs, the Bhiwandi awareness workshops address issues of gender directly.

These sessions with young people were designed in response to a needs assessment in Bhiwandi that identified adolescents' lack of opportunity to reflect on values. The sexual and reproductive health sessions explore issues such as relationships, emotions, and the relative power and value attributed to boys versus girls. "It's a real challenge to develop a curriculum that shows them how to deal with emotions such as anger and shows them how to express or overcome their feelings," says Vaishali Thakur, a counselor at FPAI's Bombay branch. "These issues are not emphasized in (traditional) curricula on reproductive and sexual health."

In addition to the teen workshops, the community program conducts outreach to teachers, training for adolescent peer educators, and public education campaigns aimed at young people. For example, at a workshop on "Our daughters, our assets," 60 teenage girls and boys learn how a preference for sons has resulted in an adverse male-female sex ratio in India. "Here, we hear things that our parents never talk about," says one young woman.

Dr. Kanbur sees the community activities as a critical avenue for helping young people to challenge existing assumptions about gender. "Men should be more aware of sexual problems," he says. "Men just won't attend the clinic. Men are the superior lot, so they assume they are normal. The root cause is that we treat our boys and girls differently."

The community-education team also meets with adult women. Among their concerns are reproductive tract infections, although they do not necessarily link this common problem to a risk of infertility. For example, women explain that during menstruation, they must use the common well to wash their sanitary cloths (only about 5 percent can afford sanitary napkins), and they feel embarrassed to have the drainage water turn red in front of others. As a result, they often wear the same cloth for as long as possible while they await a chance to wash it when no one else is at the well. The staff explain to the women that the longer they wear the cloth, the greater their chance of developing or nurturing an infection of the reproductive tract. The staff encourage the women to put their health first, to wash the cloths well before wearing them, and to wash them indoors when they have a bath. 
The outline of a teenage girl's body is traced on a bright yellow sheet of paper, and the girls are asked to map female body parts within the outline. Although they are ready to map eyes, ears, and noses, they have to be coaxed into mapping reproductive and sexual organs. "So what did you do when you got your first period?" asks Sunanda, as she draws -and explains - the function of the uterus. "Told my mother," says one girl. "And what did she tell you?" "Nothing."

Nothing. It is this absence of information from other sources that makes this sexuality education workshop a unique learning experience in the lives of young men and women in rural Bhiwandi. The Bhiwandi staff focus on both technical and social issues. Understanding fertility is part of understanding - and hopefully preventing-infertility. Dr. Kelkar notes, "While explaining menstruation, we explain when ovulation takes place." Using a flip chart, Sunanda teaches the girls about different methods of contraception, including condoms. She asks them whether they knew about STIs. Some girls nodded shyly, but were not sure what they were. Sunanda provides them with basic information about such infections.

In addition to awareness workshops, with the help of local mahila mandals, community-level diagnostic camps are held to detect ailments that can then be treated at the clinic. The camps are usually held in the village anganwadi (community center) or in someone's house, and are usually preceded by a mahila mandal meeting to educate the women about reproductive health issues. About 25 to 30 women are examined in each one-day camp, and staff provide antenatal checkups, RTI screening, and (for women older than 30) pap smears. A specific test for infertility is not performed, but some women are referred through the camps for infertility treatment.

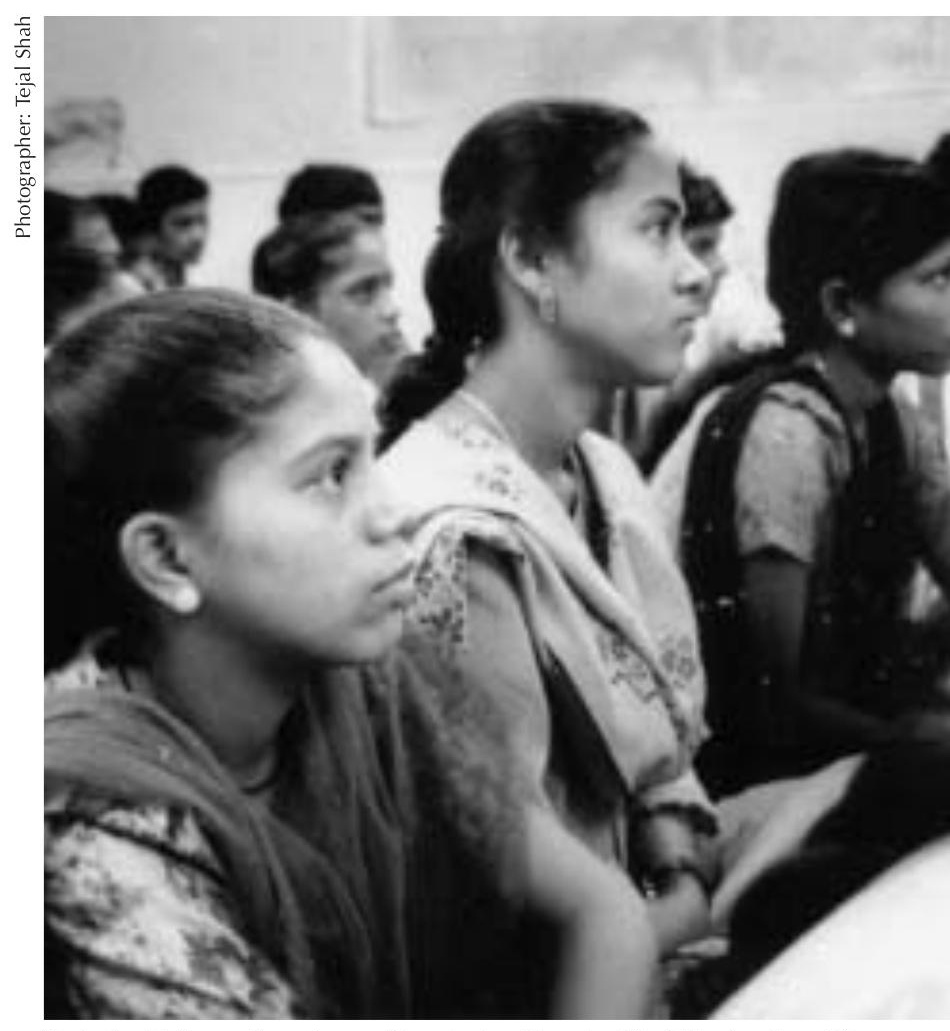

Technical information alone will make hardly a dent in STI rates. In addition to providing information about topics such as STIs, the Bhiwandi awareness workshops address issues of gender directly.

\section{Achievements of the Bhiwandi Infertility Program}

In addition to the 70 infants whose parents might otherwise despair of ever having a family, the Bhiwandi staff can take pride in a number of broader social and institutional accomplishments. Some of these are direct benefits of the infertility clinic, whereas others are gains resulting from the broader comprehensive reproductive health project of which the infertility program is a part.

\section{Improved Spousal}

Relations and Changed Attitudes among Men

The counseling available at the clinic has helped hundreds of couples to work 
through an overwhelming sense of shame and tension, and has helped them to understand that the wife should not automatically bear blame for not becoming pregnant. According to Dr. Kelkar, clinic staff are seeing a change in men's attitudes and greater mutual support between husbands and wives.

As a result of community workshops and of men's seeing that some women are able to conceive after their husbands are treated at the clinic, this awareness is spreading to men in the community. "It is amazing," says Dr. Rao. "Normally,

\section{With better resources, the clinic could teach more women to determine when they are ovulating and could better assist couples to cope with their ultimate failure to conceive.}

who had hydrocoele, and could not stand, work, sleep, or get married as a result.

\section{Increased Use of the Bhiwandi Clinic}

The Bhiwandi clinic enjoys a strong relationship with the community, because the clinical program grew out of the mahila mandals. Clearly, the community particularly values an institution that provides assistance to infertile couples. As Dr. Rao expresses it, "This treatment is seen as a pro, a positive. When we do family planning, we're 'stopping birth,' which is not seen as a positive."

Furthermore, the infertility clinic has contributed to the general willingness of people to seek reproductive health care. Compared with a service like family planning, the successful results of infertility treatment are visible. Of course, not all of the increased use of the Bhiwandi clinic is the result of its infertility service; the broad array of reproductive health services that it offers undoubtedly fosters the rise in client volume. Professor Gadre believes that the key to the clinic's success is in the very name of the project: Comprehensive Reproductive Health for All. Pravina Palaye echoes this view: "When we started giving all other reproductive health services, patients started accepting family planning. This is the reproductive health phenomenon." Indeed, as Table 1 shows, the greatest increase in client load by far has been in family planning.

\section{Enhanced Capacity among Staff}

The Bhiwandi project now relies on a sophisticated clinical and communitybased provider team. Staff members are comfortable discussing issues related to sexual health. Says Pravina, "We used to feel embarrassed to talk about the penis. 
Table 1 Number of clients at Bhiwandi clinic, by type of service and year

\begin{tabular}{lrrrrrr}
\hline Clinic services & 1997 & 1998 & 1999 & 2000 & 2001 & Total \\
\hline Infertility treatment & 194 & 170 & 154 & 107 & 92 & 717 \\
Other reproductive health services & 508 & 918 & 973 & 412 & 317 & 3,128 \\
Family planning & 101 & 646 & 1,135 & 992 & 1,162 & 4,036 \\
Total & 803 & 1,734 & 2,262 & 1,511 & 1,571 & 7,881 \\
\hline
\end{tabular}

When we started discussing these things, the women started talking openly. My own development happened here."

\section{Remaining Challenges}

Five years after having launched the infertility program, as FPAI continues to implement the Cairo agenda in its 43 clinics throughout India, the Comprehensive Reproductive Health for All project serves as an institutional model. The Bhiwandi staff and their colleagues at FPAI in Bombay take pride in their accomplishments and look toward the future. At the same time, they consider ways they might, with more resources and time, better meet the needs of the women and men they serve. Among the challenges they face are:

- Expanding clinical services. The staff hope to find the resources to enable more couples to try assistedreproduction technologies. With more time, staff could follow up couples referred for these technologies to determine their success rates.

- Strengthening in-clinic education and counseling components. With better resources, the clinic could assess what might be gained from more comprehensive education and counseling. For example, to help women determine when they are ovulating, staff might include routine instruction about standard days (or "necklace"), temperature, and/or mucus methods. Providers could then screen women for anovulation. It would also help couples time intercourse (especially important if one tube is blocked and the opportunity for fertilization occurs only once every two months), and give them some measure of control at a time when they feel particularly powerless.

The program might also strengthen counseling that would assist couples to cope with their failure to conceive. With increased resources, a staff member could provide such counseling, start a support group for infertile couples, or strengthen adoption counseling. In following up couples who have been referred for more sophisticated treatment to learn about the medical outcomes of the referral, staff might also be able to ask and learn about the emotional costs to clients of trying costly and invasive procedures without success vis-à-vis accepting childlessness without undergoing these procedures.

- Strengthening community-based education. To develop stronger links between awareness and services, and between the community and the clinic, the staff are encouraging the mahila mandals and yuvak mandals (voluntary men's groups) to strengthen their role in communitybased education, health promotion, and referral. 


\title{
An Experience from Nigeria: Women's Health and Action Research Centre
}

\author{
Although the particular cultural meaning of infertility varies from one setting to \\ another, a general pattern is found in many settings that includes a tendency to blame \\ the woman, together with a great unmet need for services. To provide a comparative \\ glimpse of a reproductive health program tackling the problem of infertility in anoth- \\ er region, a brief review of the work of the Women's Health and Action Research Centre \\ (WHARC) in Benin City, Nigeria is included here.
}

Throughout sub-Saharan Africa, infertility is a serious reproductive health problem. Although the Women's Health and Action Research Centre offers comprehensive reproductive health care (including family planning, postabortion counseling, testing and treatment for STIs, and general gynecology), as many as 70 percent of the women voluntarily walking into the clinic are seeking help to conceive. The primary cause of infertility in this region is tubal scarring in women, a consequence of sexually transmitted infections. Low sperm counts (of various origins) are the next most common cause of infertility in the client population.

To learn more about the problem of infertility locally, WHARC conducted a population-based prevalence study in 1997, which found that one of five couples was infertile (that is, the couple had failed to conceive after two years of engaging in regular sexual intercourse without the use of contraceptives). A second survey found that women named infertility services as their primary reproductive health need.

It is not surprising that unwanted childlessness is such a pressing issue. Not being able to bear children can be a sad and stressful situation anywhere, but in Nigeria, as in India (and indeed in many countries), the consequences of infertility are particularly severe for women. Even when the cause is of male origin, the woman is blamed for childlessness. Her husband may beat her, either as punishment or simply out of frustration. He may choose-or feel pressured by his family-to take an additional wife. Frequently, the childless woman is disinherited or divorced. Among the Ekiti people of southwest Nigeria, a woman who dies without leaving offspring must be buried outside of the city.

In many ways, the WHARC experience parallels that of the Bhiwandi clinic in India. Half of the infertility clients are referred by other doctors, and many have already sought help from traditional or religious healers. Usually, the woman first comes to the clinic by herself. WHARC staff require, however, that her husband come back with her; in recent years, most men are willing to do so.

At WHARC, along with conducting an extensive history and clinical work-up, staff teach women how to tell when during the menstrual cycle they are fertile. Clients learn the calendar method and then how to identify the changes in cervical mucus during the cycle. Leaflets are available to complement the instruction. Learning this method has enabled some couples to conceive.

Among women who ovulate infrequently or irregularly, instruction for identifying the time of ovulation so that intercourse may be synchronized can be helpful. However, many of the 350 couples who come to WHARC each year need different treatments, including induction of ovulation, varicocoele repair, and tubal 
repair. The majority of successful pregnancies have occurred among couples undergoing ovulation induction, whereas pregnancy rates following tubal repair have been particularly poor. Among those who might benefit from in vitro fertilization, the few with financial resources are referred to a clinic in the UK; two out of six of such referrals have resulted in pregnancy. Finally, WHARC staff sometimes counsel clients to adopt a child. Babies are available for adoption in Nigeria, but, according to Dr. Friday Okonofua, Director of WHARC, strong cultural taboos remain against adoption. Also, because the belief is widespread that the abili-

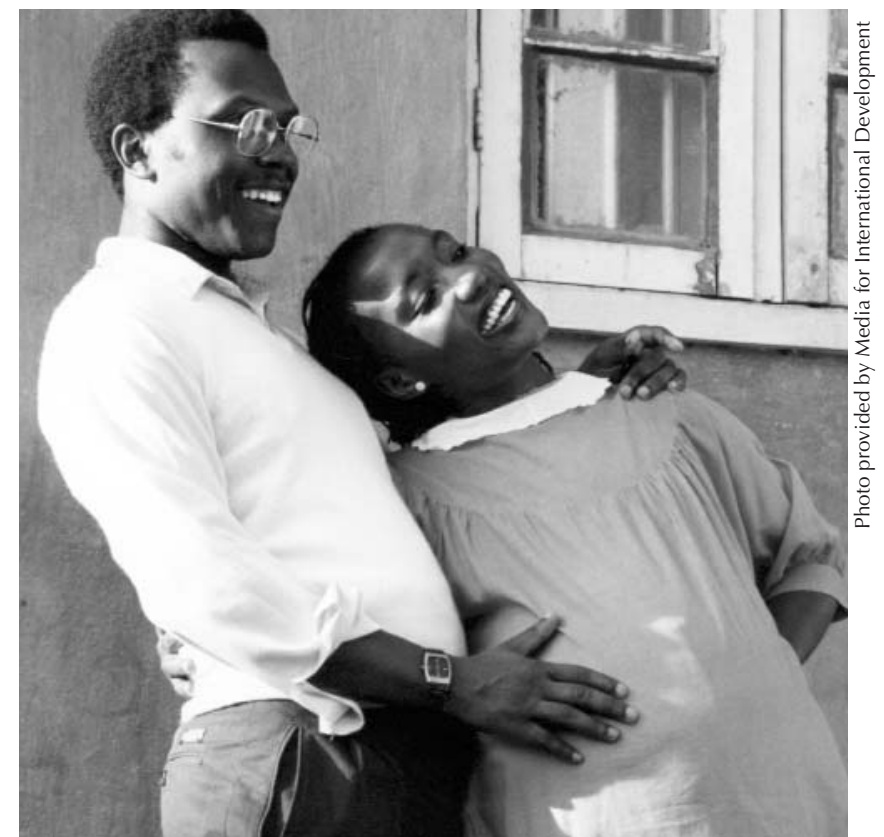

Some WHARC clients became pregnant after learning methods of fertility awareness. Identifying ovulation may be particularly helpful to women who have one blocked fallopian tube (and hence, opportunities for fertilization and implantation only on alternate cycles). ty to conceive is controlled by spirits, people maintain hope. They may return to a traditional healer, but are unlikely to accept the finality of childlessness. To date, only one couple has adopted.

WHARC is committed to addressing the epidemic of infertility at its root and is actively engaged in community education to reduce the prevalence of STIs. One part of that challenge is changing sexual behavior norms and promoting condom use. Dr. Okonofua is particularly hopeful that the female condom can provide women with a way to protect themselves when their partners are unwilling to use a condom. He stresses, however, that some of the problem with stubborn STI rates is at the provider level. In one study, WHARC found that less than two percent of STIs are being treated correctly. WHARC is currently training providers (including traditional healers) to improve the quality of STI diagnosis and treatment. Even with syndromic approaches, providers can improve diagnosis and prescribe drugs that are more appropriate to particular conditions. A need remains for better education concerning condom use and better partner follow-up if treatment is to be effective. Of course, even with proper diagnosis and treatment, Dr. Okonofua laments, financial constraints are the biggest problem. Clients often simply cannot afford to pay for necessary medications.

Although WHARC has not been successful in helping most infertile couples achieve pregnancy, the fact that they offer any help is of great value to their clients. The infertile couple takes some comfort from the compassion and efforts of a health-care provider, and the community values a clinic that honors and responds to the needs it identifies. 
The Challenge for

\section{Family Planning}

Programs:

\section{Is Infertility Too Difficult to Take On?}

At one time, both the Family Planning Association of India and WHARC of Nigeria felt overwhelmed by the idea of responding to the problem of infertility. The demand seemed too great to meet. The task of building technical knowhow was intimidating. The cost of providing care could soar out of control. The relations with local private doctors might be jeopardized. The institution itself might lose its focus.

In fact, the demand has been real, but not beyond control. Trained physicians have joined the clinics and helped to build the programs. The clinics have found a workable balance between outside support and client fees. The institutions have become strengthened both internally and within the community.

Although the staff at Bhiwandi and at WHARC are proud of their accomplish-

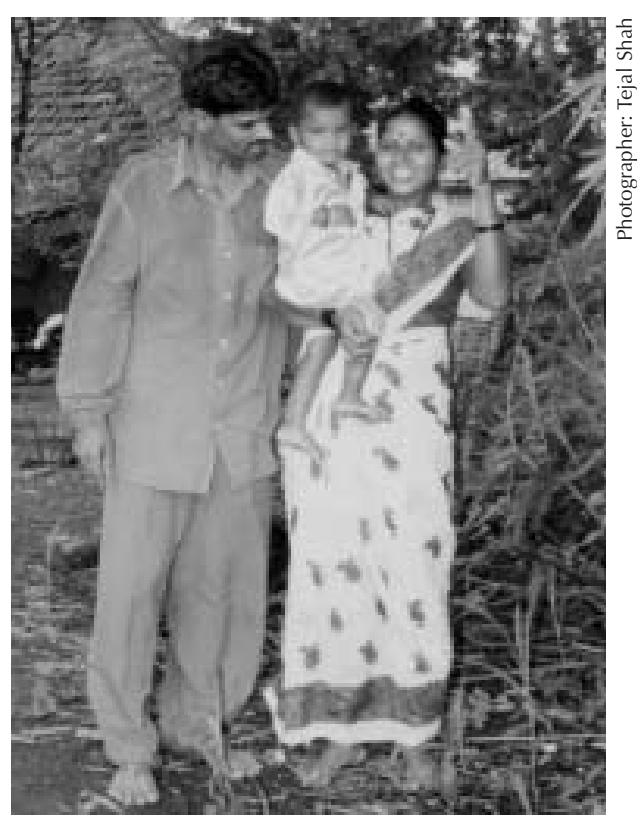

By assisting couples who want to have children as well as those who want to avoid pregnancy, family planning programs will finally become worthy of their name in the truest sense. ments, their efforts to help infertile couples conceive is, in many ways, an uphill battle; the trial is even greater for their clients. Immense personal, technical, and financial efforts over a long period translate into few triumphs. Staff know their job is not, and will never be an easy one, and they try to face as squarely as they can a constellation of related challenges. Despite the long odds and sometimes wrenching disappointments, these infertility clinics are happy places. The staff take great satisfaction from the benefits they have helped bring about for their clients and for the communities in which they live.

Understandably, many program leaders feel they lack the resources or space to provide the range of infertility services offered at Bhiwandi and in Benin City. A number of discrete and highly valuable services can be offered, however, that require little in the way of extra equipment or staff. For example, as noted above, counselors can teach women how to tell when they are ovulating, which can help the clinic screen for anovulation, help women synchronize intercourse with ovulation, and give clients a desperately needed measure of control over the process of their treatment. Clinics can also provide basic counseling for male partners and offer simple exams to screen for problems such as varicocoele. For a useful framework of discrete services that can be provided with different levels of infrastructure and program effort, see the afterword to this article.

Certainly, every program can wrestle with the question of what the words "family planning" really mean. This process is both a pragmatic and, ultimately, a philosophical one. Despite the limits of their achievement, the staff at Bhiwandi and in Benin know that they now have a better answer for such women as the one who faced the FPAI field-worker some years back and asked, "What about us?" 


\section{Lessons Learned}

FPAI and WHARC have learned several important lessons as part of their experience in managing infertility treatment within a comprehensive reproductive health framework.

- A serious and generally unacknowledged unmet need exists for affordable infertility services.

- Some infertility services can be offered within the context of typical family planning clinics (see the afterword for a framework for incorporating infertility into family planning and reproductive health services). With minimal additional training for physicians (or specialists who work at the clinic on a part-time basis), a program can manage a significant number of cases without referral to costly specialty clinics.

- Even in resource-poor settings, clients are willing to pay for services because they greatly value help in overcoming childlessness. A significant portion of a clinic's costs can be covered by fees charged to clients.

- Male involvement is essential to effective infertility treatment and care.

- Counseling and education are integral aspects of treating infertility. Infertility services must be conceptualized as a balance between a medical and social model of care.

- Information about causes and prevention of infertility can be incorporated easily into existing community education programs on sexual and reproductive health and gender. Screening for infertility also dovetails effectively with STI screening and treatment services.

- In light of the low rates of clinical success in treating infertility, programs must devise thoughtful indicators to evaluate program effectiveness. Among valued outcomes may be that of helping couples to avoid unnecessary and inaccurate blaming of one partner and aiding them to resolve their situation of childlessness in a manner that they deem helpful.

- Offering support and services for infertile couples builds community support for and use of a reproductive health program.

\section{References}

Anonymous. 1999. "Notes from a support group for women over 40 trying to have their first child." Reproductive Health Matters 7(13): 89-95.

Dawn, C.S. 1995. Textbook of Gynaecology, 12th edition. Kolkata, India: Dawn Books.

International Planned Parenthood Federation (IPPF). 1996. Charter on Sexual and Reproductive Rights (Article 10.1). London: IPPF P.23. Also available at: <http://www.ippf. org/charter/full.htm>

Jeejeebhoy, Shireen. 1998. "Infertility in India-levels, patterns and consequences: Priorities for social science research." Journal of Family Welfare 44(2):15-24.

Murthy, Nirmala, Lakshmi Ramachandar, Pertti Pelto, and Akhila Vasan. 2002. "Dismantling India's contraceptive target system: An overview and three case studies." In Haberland and Measham (eds.). Responding to Cairo: Case Studies of Changing Practice in Reproductive Health and Family Planning. New York: Population Council.

Pachauri, Saroj. 2001. "Male involvement in reproductive health care." Journal of the Indian Medical Association 99(3): 138-142.

Parikh, F.R. et al. 1997. "Genital tuberculosis: A major pelvic factor causing infertility in Indian women." Fertility and Sterility 67(3): 497-500.

Sher Institute for Reproductive Medicine (SIRM). 2002. "Pelvic tuberculosis: An uncommon cause of infertility in the United States (1999-2001)." <http://haveababy. com/infert/pelvictb.asp>

Unisa, Sayeed. 1999. "Childlessness in Andhra Pradesh, India: Treatment-seeking and consequences." Reproductive Health Matters 7(13): 54-64.

Walsh, Patrick and M. McDougall. 1992. Campbell's Urology, 6th edition. Philadelphia: Saunders. 


\title{
Afterword
}

\author{
by Friday Okonofua
}

Family planning programs can be an important entry point for couples with all types of fertility problems-those who seek to limit their fertility as well as those wishing to conceive. Without mounting large-scale and complex interventions, family planning programs can play a critical role in preventing and treating some aspects of infertility (Rowe 1999). In doing so, they can help many couples in need directly; involve men in reproductive health care; help reduce STI and RTI rates; and win trust from communities. A possible frame- work for incorporating limited infertility care into a family planning or reproductive health program is provided below. Programs in settings with significant unmet need for infertility care may wish to consider which services they might reasonably begin to deliver.

\section{Reference}

Rowe, Patrick John. 1999. "Clinical aspects of infertility and the role of health care services." Reproductive Health Matters 7(13): 103-110.

\section{Education and Couns eling}

Information and counseling related to fertility and infertility should be part of the constellation of services available at all family planning clinics. Education is critical for couples to make informed decisions about seeking care, and some cases of infertility can be largely resolved with information. Family planning programs can:

- tell women who ask about fertility concerns that men may also be infertile and encourage them to bring their husbands to the clinic for a joint consultation;

- teach women (including illiterate women) methods of fertility awareness to help them determine if and when they are ovulating;

- talk with couples to ensure that the timing and nature of their sexual activity can allow for fertilization; and

- provide printed information about infertility as well as contraceptive methods. 


\section{Preliminary Clinical Services}

With proper training, staff can provide some simple but critical infertility treatment services at family planning clinics. These include:

- free or low-cost pregnancy testing at flexible or convenient hours. This service should be so advertised that it is welcoming to all couples regardless of their intent. Many women who are trying to become pregnant agonize as they wait for a late period, or they invest in costly home pregnancy tests. Providing pregnancy testing would not only provide clinical results for these women and their partners, but for those with a negative test result, it could serve as an opportunity for educating and counseling couples trying to conceive;

- semen analysis;

- advice for men on how to boost sperm count, such as avoidance of excessive alcohol, tobacco, and tight underwear;

- where appropriate and feasible, prescription of ovulatory drugs such as clomiphene citrate for women with confirmed minor ovulatory problems.

\section{Referrals}

For couples who fail to conceive after initial testing and counseling interventions, programs can (where available):

- refer them to higher levels of infertility management;

- provide counseling to help them come to terms with their situation or to consider adoption, and provide the appropriate referrals (to adoption agencies and for further counseling).

\section{Prevention of Infertility}

Finally, the cooperation of family planning programs in both the clinical and policy arenas is needed to help reduce the rate of infertility in the future. Such programs can play an important role in the following ways. They can:

- adopt and promote routine screening, testing, and treatment of sexually transmitted infections that impair fertility;

- promote the use of both male and female condoms, using thoughtful approaches and counseling;

- teach women and providers to seek antenatal care and clean delivery to reduce the risks of pregnancy-related complications;

- help improve the quality of abortion and postabortion care, particularly in settings where unsafe abortion is a significant source of infection and infertility; and

- implement community education programs that address popular myths and attitudes about infertility. 


\section{Resumen en Español}

La infertilidad afecta a hasta el 15 por ciento de las parejas en los países en vías de desarrollo. Las consecuencias sociales del problema son serias en sociedades que valoran a las mujeres principalmente por su capacidad reproductiva y donde se las culpa por cualquier dificultad en la concepción. La posibilidad de diagnosticar y tratar la infertilidad en muchas de esas sociedades se encuentra fuertemente limitada por la falta de capacitación y recursos. Es más, las políticas nacionales y los donantes internacionales raramente tratan de ayudar a las parejas que no pueden concebir. Esta edición de $Q / C / Q$ informa sobre los servicios para la infertilidad ofrecidos por dos clínicas de planificación familiar en comunidades de bajos ingresos, una en India y otra en Nigeria.

La clínica de la Asociación de Planificación Familiar de India en Bhiwandi ofrece servicios para la infertilidad como parte de sus servicios su agenda en salud reproductiva. Dado que muchos varones se niegan a reconocer su propio papel potencial en la infertilidad, la clínica decidió requerir que la pareja, y no sólo la mujer, debe someterse al examen medico. Durante la entrevista clínica, los médicos preguntan sobre prácticas sexuales, tipo de trabajo, etc. Para los hombres, la revisión preliminar incluye pruebas para ITS y VIH, análisis de semen, y un examen físico. El tratamiento puede incluir educación sobre factores que afectan la espermatogénesis, la reparación del varicocele, e inseminación artificial. El procedimiento básico para mujeres incluye exámenes físicos y ginecológicos, análisis del moco cervical, y ensayos hormonales; entre las intervenciones utilizadas se encuentran la laparoscopia, los fármacos para la fecundidad y la educación sobre los períodos fértiles de la mujer.

Dado que ni los clientes ni la clínica pueden acceder a tecnologías sofisticadas, los doctores no logran diagnosticar o tratar muchos casos. Sin embargo, 75 de las 717 parejas atendidas entre 1996 y 2001 lograron un embarazo, y 25 más fueron derivadas para tratamientos adicionales.

Dado que la infertilidad suele causar mucho estrés, y que las posibilidades de un tratamiento exitoso son bajas, para muchas parejas el beneficio principal de la atención consiste en sentirse menos igno- rantes y más cómodos con su situación. En Bhiwandi los doctores están a cargo de la consejería sobre infertilidad. Aunque tratan de ofrecer todo el apoyo y la información posible, tienen que atender simultáneamente a varias tareas clínicas, por lo cual todavía quedan oportunidades para responder mejor a las necesidades emocionales de los clientes.

Con el fin de evitar la infertilidad futura, el programa ofrece tratamiento para ITS y educación comunitaria sobre infecciones, las relaciones de género y la infertilidad. Otro logro del programa incluyeque juegan los varones mejoras en la imagen pública en la comunidad y aumento en el uso de todos los servicios de la clínica.

En Ciudad de Benin, Nigeria, el Centro de Acción e Investigación en Salud de la Mujer (en inglés, WHARC) empezó a ofrecer servicios para la infertilidad cuando un estudio local encontró índices de infertilidad del 20 por ciento, y cuando una encuesta mostró que las mujeres consideraban que la atención para este problema era su principal necesidad. Aquí también el personal insiste que los varones asistan a la clínica. Los índices de éxito no son altos, pero tanto los clientes como la comunidad local valoran profundamente el servicio. EI WHARC también busca atender a la causa fundamental de la infertilidad-las ITS. Los dirigentes de la clínica esperan que las mujeres locales adopten el condón femenino, y están trabajando con proveedores de servicios para mejorar el diagnóstico y tratamiento de las ITS.

Los dos programas ofrecen las siguientes lecciones:

- Existe una importante demanda insatisfecha por los servicios para la infertilidad; incluso los clientes de bajos recursos están dispuestos a pagar por dichos servicios.

- La orientación y la educación, así como la participación de los varones, son la clave para el éxito.

- Los programas de planificación familiar se pueden convertir en importantes puntos de entrada para parejas con problemas de infertilidad al proveer servicios limitados. Estos pueden ser la educación la consejería; algunos servicios clínicos; y derivaciones a otros servicios. 


\section{Résumé en Français}

La stérilité touche jusqu'à 15 pour cent des couples dans les pays en développement. Les conséquences sociales sont particulièrement graves dans les sociétés où la valeur des femmes dépend en grande partie de leur capacité reproductrice et où elles sont blâmées si elles n'arrivent pas à concevoir. La capacité de diagnostiquer et traiter la stérilité dans plusieurs de ces contextes est toutefois entravée par le manque de formation et de ressources. En effet, les politiques nationales et les bailleurs de fonds internationaux donnent rarement de l'aide aux couples incapables de procréer. Ce numéro de Quality/Calidad/Qualité décrit les services de stérilité offerts par deux centres de planification familiale dans des communautés pauvres en ressources, en Inde et au Nigeria.

La clinique de L'Association de planification familiale d'Inde à Bhiwandi a commencé à offrir des soins aux personnes stériles dans le cadre d'un programme élargi de santé de la reproduction. Beaucoup d'hommes ne reconnaissant pas leur rôle potentiel dans la stérilité, le centre a décidé d'exiger que le couple subisse des tests de dépistage. Au cours de l'entretien clinique, les médecins se renseignent sur les pratiques sexuelles, le type de travail, etc. Les tests préliminaires pour les hommes incluent le dépistage des IST et du VIH, un spermogramme et un examen physique. L'éducation sur les facteurs ayant une incidence sur la spermatogenèse, le traitement des varicocèles et l'insémination artificielle figurent parmi les options de traitement. Le dépistage de base pour les femmes comprend les examens physique et gynécologique, I'analyse de la glaire et les essais hormonaux. La laparoscopie, les médicaments contre la stérilité et l'éducation sur la période féconde sont certains des outils dont disposent les prestataires.

En partie parce que ni les clients ni le centre médical ne sont en mesure de s'offrir des technologies sophistiquées, les médecins ne peuvent pas diagnostiquer ou traiter beaucoup de cas. Quand même, de 1996 à 2001, 75 couples sur 717 ont réussi à obtenir une grossesse. Vingt-cinq autres ont été référés pour un traitement supplémentaire.

Vu que la stérilité peut être stressante et que les chances de réussite du traitement sont faibles, un avantage des soins pour les couples est l'augmentation des connaissances et du réconfort. A Bhiwandi, les médecins sont chargés de conseiller les personnes stériles. Bien qu'ils s'efforcent de fournir le plus d'information et de soutien possible, ils doivent aussi se concentrer sur une gamme de tâches cliniques. En conséquence, il reste du chemin à faire pour répondre aux besoins émotifs des clients.

Pour prévenir la stérilité future, le programme offre le traitement des IST et l'éducation communautaire sur les infections, les relations entre les sexes et la fécondité. D'autres réalisations du programme comprennent une meilleure image du centre au sein de la communauté et un plus grand recours au centre pour tous les services.

A Benin City, au Nigeria, le Centre d'action et de recherche pour la santé des femmes (WHARC, Women's Health Action and Research Centre) a commencé à offrir des soins de stérilité quand une étude locale a révélé un taux de prévalence de la stérilité de 20 pour cent, et qu'une enquête a établi que les femmes percevaient les soins de stérilité comme leur plus grand besoin. Ici comme à Bhiwandi, le personnel doit insister pour que les maris se présentent au centre médical. Les taux de réussite ne sont pas élevés, mais l'aide offerte par le centre est très appréciée, tant par les clients que par la communauté. Le WHARC s'est aussi engagé à s'attaquer à la cause première de la stérilité : les IST. Les responsables espèrent que les femmes adopteront le préservatif féminin, et ils collaborent avec les prestataires pour améliorer le diagnostic et le traitement des IST.

Les leçons tirées de ces deux programmes sont les suivantes :

- Il existe un sérieux besoin non satisfait de services de stérilité abordables ; même les clients pauvres sont prête à payer pour les services.

- Les conseils, l'éducation et la participation des hommes sont des aspects clés des soins de stérilité.

- Les programmes de planification familiale peuvent devenir un important point d'entrée pour les couples ayant des problèmes de fécondité en offrant des services restreints tels que l'éducation et les conseils, certains services cliniques ainsi que des références éclairées. 


\section{About the Authors}

Friday Okonofua is Executive Director of the Women's Health and Action Research Center, Benin City, Nigeria; Dean of the School of Medicine, University of Benin, Benin City, Nigeria; and Adjunct, Department of International Health, Karolinska Institute, Stockholm, Sweden.

Bishakha Datta is Programme Director of Point of View, a nonprofit organization in Bombay, India that promotes the points of view of women through creative use of media. A journalist by training, she makes documentary videos and writes articles, essays, and books on issues related to sexuality, reproductive health, and women's rights.

\section{Production Staff}

Editor: Debbie Rogow

\section{Research and editorial assistant:}

Michelle Skaer

Project editor: Karen Tweedy-Holmes

Designer: Mike Vosika

Translators: Paul Constance (Spanish) and Jeannette Ndong (French)

$\begin{array}{ll}\text { A d v is o ry } & \text { Gro u p } \\ \text { Errol Alexis } & \text { Suellen Miller } \\ \text { Gary Barker } & \text { Isaiah Ndong } \\ \text { Judith Bruce } & \text { Nancy Newton } \\ \text { Susana Galdos } & \text { Saumya Ramarao } \\ \text { Françoise Girard } & \text { Julie Reich } \\ \text { Nicole Haberland } & \text { Ann Starrs } \\ \text { Judith F. Helzner } & \text { Cynthia Steele } \\ \text { Katherine Kurz } & \text { Gilberte Vansintejan } \\ \text { Ann Leonard } & \text { Beverly Winikoff } \\ \text { Ann McCauley } & \text { Margot Zimmerman } \\ \text { Liz McGrory } & \end{array}$

Comprehensive Reproductive Health for All

Drs. Ajay Kanbur and Kelyani Kelkar

FPAI, PSK

37 Prabhu Alley, Near Raka Bhavan, Mandai, Bhiwandi 421305, Dist. Thane,

Maharashtra, India

Phone: +952522 58752; fpaipsk@sanchar.net.in

Women's Health and Action Research Centre

Dr. Friday Okonofua

4 Alofoje Street, off Uwasota Rd

Box 10231, Ugbowo

Benin City Edo State, Nigeria

wharc@hyperia.com

We invite your comments and ideas for projects that might be included in future issues of Quality/Calidad/Qualité. If you would like to be included on our mailing list, please send an e-mail to: qcq@popcouncil.org. Most past editions are available online at: www.popcouncil.org/publications. The following are also available in print; single or multiple copies may be ordered by e-mail:

Celebrating Mother and Child on the Fortieth Day: The Sfax Tunisia Postpartum Program (English only), no. 1, 1989.

Man/Hombre/Homme: Meeting Male Reproductive Health Care Needs in Latin America (English, Spanish), no. 2, 1990.

Gente Joven/Young People: A Dialogue on Sexuality with Adolescents in Mexico (English, Spanish), no. 5, 1993.

The Coletivo: A Feminist Sexuality and Health Collective in Brazil (English, Portuguese), no. 6, 1995.

Doing More with Less: The Marie Stopes Clinics of Sierra Leone (English only), no. 7, 1995.
Introducing Sexuality within Family Planning: Three Positive Experiences from Latin America and the Caribbean (English, Spanish), no. 8, 1997.

Using COPE to Improve Quality of Care: The Experience of the Family Planning Association of Kenya (English, Spanish), no. 9, 1998.

Alone You Are Nobody, Together We Float: The Manuela Ramos Movement (English, Spanish), no. 10, 2000.

From Patna to Paris: Providing Safe and Humane Abortion (English only), no. 11, 2001.

Universal Sexuality Education in Mongolia: Educating Today to Protect Tomorrow (English only), no. 12, 2002. 